\title{
Alternative compensation mechanisms as remedies for uninsurability of liability
}

Citation for published version (APA):

Faure, M. G. (2004). Alternative compensation mechanisms as remedies for uninsurability of liability. Geneva Papers on Risk and Insurance Theory, 29(3), 455-489. https://doi.org/10.1111/j.1468-

0440.2004.00297.x

Document status and date:

Published: 01/01/2004

DOI:

10.1111/j.1468-0440.2004.00297.x

Document Version:

Publisher's PDF, also known as Version of record

Document license:

Taverne

Please check the document version of this publication:

- A submitted manuscript is the version of the article upon submission and before peer-review. There can be important differences between the submitted version and the official published version of record.

People interested in the research are advised to contact the author for the final version of the publication, or visit the DOI to the publisher's website.

- The final author version and the galley proof are versions of the publication after peer review.

- The final published version features the final layout of the paper including the volume, issue and page numbers.

Link to publication

\footnotetext{
General rights rights.

- You may freely distribute the URL identifying the publication in the public portal. please follow below link for the End User Agreement:

www.umlib.nl/taverne-license

Take down policy

If you believe that this document breaches copyright please contact us at:

repository@maastrichtuniversity.nl

providing details and we will investigate your claim.
}

Copyright and moral rights for the publications made accessible in the public portal are retained by the authors and/or other copyright owners and it is a condition of accessing publications that users recognise and abide by the legal requirements associated with these

- Users may download and print one copy of any publication from the public portal for the purpose of private study or research.

- You may not further distribute the material or use it for any profit-making activity or commercial gain

If the publication is distributed under the terms of Article $25 \mathrm{fa}$ of the Dutch Copyright Act, indicated by the "Taverne" license above, 


\title{
Alternative Compensation Mechanisms as Remedies for Uninsurability of Liability
}

\author{
by Michael G. Faure*
}

\section{Introduction}

One of the crucial issues resulting from expanding liability risks is whether alternative compensation mechanisms, other than (liability) insurance might be better able to cover socalled uninsured risks. Generally it is held in the literature that the issues that threaten the insurability of (liability) insurance today (uncertainty concerning probability and damage, causal uncertainty, retroactivity issues) would also affect other compensation mechanisms. Indeed, it is often held, for instance, that the general idea that no matter what type of compensation system one looks for it should always be organized in such a manner that the one who creates the risk should also bear the financial consequences, is an element which is crucial for every type of compensation mechanism. Hence, the question arises whether the reasons for uninsurability in traditional (liability) insurance could be removed if one would seek alternative compensation mechanisms.

This question is warranted, especially after the Twin Towers incident of 11 September 2001 which indicated that catastrophes can occur that largely outweigh the capacity of traditional insurance undertakings. Therefore in this paper I will on the one hand analyse whether insurance compensation mechanisms other than traditional liability insurance would be better able to cover "uninsurable" risks under some circumstances. In addition, I would like to examine whether other financial arrangements (this is different from insurance) would be able to provide financial compensation if risks remained uninsured through the traditional insurance markets. ${ }^{1}$ In that respect the question obviously arises why other compensation mechanisms would be better able to cover those particular risks than insurance.

In this paper I will look at some of these alternative mechanisms, not only from an insurance theoretical point of view, but also by looking at some actual compensation mechanisms which have been used in practice. Indeed, for many risks such as highly technological risks, nuclear risks and other so-called "systemic risks" industrial operators themselves have already moved away from traditional liability insurance and have searched alternative financial mechanisms to cope with the risks to which they are exposed.

\footnotetext{
* Professor, METRO, Faculty of Law, Maastricht University, The Netherlands. This paper was first presented at the 18th M.O.R.E. Seminar on Uninsured Risks, Vouliagmeni, Athens, November 2003.

1 This paper therefore extends earlier research in this domain I concluded with David Grimeaud (M. Faure and D. Grimeaud, "Financial assurance issues of environmental liability", in M. Faure (ed.), Deterrence, insurability, and compensation in environmental liability. Future developments in the European Union, Wien, Springer, 2003, pp. 7-255) and with Ton Hartlief (M. Faure and T. Hartlief, Insurance and expanding systemic risks, Paris, OECD, 2003). I am grateful to the participants in the 18th M.O.R.E. Seminar on Uninsured Risks for useful comments on an earlier version of this paper.
} 
Within the scope of this paper I will first of all briefly discuss the tendency advocated in the literature to use capital markets to provide coverage for systemic risks (section 2). Next, I will briefly discuss the notion of self-insurance, examine it critically and look at some benefits and potential disadvantages (section 3). An important tendency within the insurance world today, especially in the area of environmental insurance, is to move away from liability insurance towards first-party or direct insurance. This tendency can be noted more particularly in the areas of medical malpractice, occupational health and environmental risks. The question therefore arises why first-party and direct insurance schemes would be better able to cover these risks than traditional liability insurance (section 4). Today, industrial operators have also introduced many alternatives, particularly risk-sharing agreements which might provide compensation at lower costs than traditional insurance. These risk-sharing agreements (sometimes also referred to as pools) therefore also merit attention (section 5). Attention will also be given to the possibility of using ex ante guarantees and deposits as instruments of financial coverage (section 6). One could also imagine that compensation funds instead of insurance would be used to cope with major catastrophic risks. Hence the question also arises whether and under what circumstances compensation funds could be considered an appropriate alternative for insurance (section 7). Finally a few concluding remarks will be formulated addressing the circumstances under which alternative compensation mechanisms could be used to cover uninsured risks.

\section{The use of capital markets to provide coverage}

It is not possible within the scope of this paper to discuss every potential alternative which could provide compensation for any damage caused. For this we can refer to the literature which has worked out other alternatives. ${ }^{2}$ Some economists, more particularly Tyran and Zweifel, have, for example, advocated the use of capital markets to provide coverage for environmental damage. ${ }^{3}$ They begin with the statement that the third-party liability as it exists fails to internalize the externality caused by the nuclear risk. They also criticize the argument of the uninsurability of the nuclear risk, noting that earthquakes are also not predictable but are nevertheless insurable and for large amounts. ${ }^{4}$ They also point to the disadvantages of the existing pooling system for nuclear risks: the cartels charge excessive premiums. In addition they criticize the limitation of liability to a value that falls far short of a possible loss, since this constitutes a subsidization of nuclear power. They then

2 For a good overview see M. Radetzki, "Private arrangements to cover large-scale liabilities caused by nuclear and other industrial catastrophes", The Geneva Papers on Risk and Insurance-Issues and Practice (GPRI), 2000, pp. 180-195. A good overview of alternative risk transfer-techniques is also provided by H. Cousy, "Van verzekering tot 'alternative risk transfer' (ART): een stap vooruit of een stap terug?", in Liber Amicorum Yvette Merchiers, Brugge, die Keure, 2001, pp. 703-722 and H. Cousy, "La fin de l'assurance? Considérations sur le domaine propre de l'assurance privée et ses frontières", in Droit et économie de l'assurance et de la santé. Mélanges en l'honneur de Yvonne Lambert-Faivre et Denis-Claire Lambert, Paris, Dalloz, 2002, pp. 121-124. See on this issue also A. Monti, Environmental risks and insurance. A comparative analysis of the role of insurance in the management of environment-related risks, OECD-report, 18 November 2002, pp. 63-64.

3 See J.R. Tyran and Zweifel, "Environmental risk internalization through capital markets (ERICAM): the case of nuclear power", International Review of Law and Economics (IRLE), 1993, pp. 431-444.

4 Tyran and Zweifel (Note 3 above), 433 report that the 1906 San Francisco earthquake caused insured damages of U.S. $\$ 39.5$ billion. This sum is 100 times greater than the maximum nuclear coverage granted by private insurers. Other examples can be given where the probabilities of an accident are unknown and the expected accident costs are large, but nevertheless large amounts of insurance coverage are provided. 
produce an alternative that is the use of capital markets to provide additional coverage for liability. Rather than turning to nuclear insurance pools, Tyran and Zweifel suggest that plant operators should be permitted to take risk-participation shares on capital markets. Investors would have the opportunity of buying such a share against deposit of financial assets, creating a warrant in favour of the plant of their choice. This warrant can be exercised by the agency when liability claims are presented. Since operators must have sufficient coverage, they will compete for coverage capital and bad risks will not be able to get coverage. Hence Tyran and Zweifel argue that their ERICAM system can correct the market failure and provide for higher coverage of the nuclear risk and improved safety.

The idea of ERICAM is that the interest rate on the bonds issued reflects the accident rate. In so far as the care of operators is observable, it will be reflected in interest rates. But when accidents are a rare event, rating will be impossible and government regulation will still be necessary. The ERICAM system has certainly advantages in the nuclear area, compared to the current system of limited liability and non-competing insurance pools. ${ }^{5}$

This idea of using capital markets to finance potential liabilities for environmental harm is, moreover, not merely theoretical. Several experiments take place with forms of socalled Alternative Risk Transfer ("ART") or securitization. ${ }^{6}$ Although it is apparently possible today to buy "catastrophe bonds" inter alia on the New York Stock Exchange, ${ }^{7}$ I will not focus in much detail on these alternatives since, according to insurers, they do not yet play a major role in Europe. ${ }^{8}$ Moreover it is argued that these "new" financing instruments, based on capital markets, will never totally replace traditional products. ${ }^{9}$

Since it is not possible to discuss all of these possible alternatives in detail in this paper, I will focus on some that can actually be found in practice, so that some empirical information on their working can be provided as well.

\section{Self-insurance and captives}

\subsection{Reserves or insurance?}

One might question whether self-insurance should be discussed at all in a paper dealing with alternatives to liability insurance, since the question really arises whether it can honestly be considered to be a realistic alternative. The reason I nevertheless want to mention self-insurance is that, although it cannot be considered "insurance", it is certainly a form of financial security. The reason I am rather sceptical about this concept of "selfinsurance" is that it is in fact a nice word, covering the situation where potentially responsible parties make reservations themselves for potential losses. However, these reserves made by the potential injurer himself cannot be considered "insurance" in the traditional sense, for the simple reason that there is no risk-spreading or risk distribution and

5 The possibilities of financial markets to manage the uncovered liabilities of industrial catastrophes are further explored in M. Radetzki and M. Radetzki, "Private arrangements to cover large-scale liabilities caused by nuclear and other industrial catastrophes", GPRI, 2000, pp. 188-193.

6 See F. Wagner, "Risk Securitization. An Alternative Risk Transfer of Insurance Companies”, GPRI, 1998, p. 575 .

7 See R.E. Smith, E.A. Canelo and A. Di Dio, "Reinventing Reinsurance using the Capital Markets", GPRI, 1997, pp. 26-37.

8 See R.E. Smith and E.A. Canelo (Note 7 above), p. 31.

9 J. Zech, "Will the international insurance market replace traditional insurance products", GPRI, 1998, p. 494. 
consequently no loss-spreading after an accident happens. ${ }^{10}$ Indeed, with self-insurance the risk will not be transferred to either an insurer, a mutual, a bank or a pool, which is typically the feature of most insurance schemes. To be blunt: self-insurance is not an insurance scheme, but a system whereby potentially responsible parties set aside reserves for future losses. Reserves can, however, be considered as tools to guarantee financial assurance; that is, however, different from insurance since reserves lack the element of risk-spreading. ${ }^{11}$

Although it can thus be argued that self-insurance does not belong in the category of financial securities which can be considered as "insurance" allowing a potentially responsible party to make reserves for future losses, it is obviously highly desirable within the central concern of this paper, which is to analyse how adequate compensation can be provided for damage through ways other than insurance. Within this focus on compensation, alternatives other than insurance have to be considered as well.

\subsection{Captives}

One could therefore question why there is often discussion about self-insurance, if it constitutes nothing other than private reserves by the potentially responsible party for future losses. The reason is usually a fiscal one. If these reserves were made without any specific goal they could be considered to be hidden profit by tax authorities and could thus be taxed. If, on the other hand, the tax system allows these reserves (and could even encourage them by making them deductible), this self-insurance becomes a way in which the potentially responsible parties could make reserves for future losses in a tax-friendly way. Often these reserves are referred to as "captives". ${ }^{12}$ These captives, to which there is often reference in the literature, are in some cases again nothing more than reserves made by larger industries to cover future losses. A captive is, according to Ranson, a reinsurance which would be owned by the insured. ${ }^{13}$ In some case, but not invariably, various industries posing the same risk could join forces via mutuals. In those cases the self-insurance would amount to pooling. In other cases the "captives" are used for reinsurance. Here a company would, for example, take out first liability insurance with an insurance company; that is referred to as a "fronting company" which may reassure with a captive. These captives can be managed by banks or (re)insurance companies. ${ }^{14}$

\subsection{Reserves as guarantees?}

A positive aspect of these tax devices that allow reserves for future losses to be set aside is obviously that there may be at least a minimum guarantee that these amounts will be used to cover future damage. However, from a policy perspective, the administrative authorities

10 With self-insurance there is indeed no risk-spreading in the traditional sense that the risk is spread over various parties that are all exposed to the risk or shifted to another who is better able to carry the risk. However, with self-insurance there may be risk-spreading in time in the sense that reserves are made for future losses.

11 Reserves, of course, allow for a risk spreading in time, but not between various parties exposed to risk.

12 See on captives and the different forms they may take: P.A. Bawcut, Captive Insurance Companies, Establishment, Operation and Management, 1991; T. Dowding, Global Developments in Captive Insurance, 1997 and Captive Insurance: a threat to the Global Insurance Industry? 1993.

13 Again, the word "reinsurance" is slightly misleading since it assumes that there is a basic insurance obligation which is reinssured.

14 J. Rogge, Les assurances en matière d'environnement, 1997, p. 38. 
controlling, for example, whether minimum financial security may be at hand, will usually be rather cautious about accepting self-insurance as proof of sufficient financial guarantee. The fact that these reserves are made today does indeed not necessarily mean that the amount will still be available at the moment the loss occurs. This is obviously the case if it is only the potentially responsible party himself who has the right to decide what will be the ultimate goal of these reserves made in the form of self-insurance. Moreover, even if the reserve were still available, if, for example, there is (environmental) damage (and the potentially responsible party has not decided to take the money with him to the Bahamas) the question will arise whether the reserve made can effectively be used to cover the loss. In the absence of specific statutory provisions, protecting the reserve as a specific security, the reserve will simply be considered to be one of the assets of the company and may thus be the subject of execution by all the creditors. If one therefore wishes self-insurance in the form of reserves and captives to be allowed as financial security for environmental damage, additional statutory measures are necessary which regulate the purpose of the money reserved by the potentially responsible party.

Self-insurance may therefore certainly play a role, as a guarantee of financial security, provided that the conditions set out above are met. This means that there needs to be a guarantee (via regulation) that the amounts set aside to this end cannot be touched by other creditors.

\subsection{Self-insurance to control moral hazard}

However, in many cases self-insurance obviously already exists today, even without this regulatory protection. In practice, many potentially responsible parties decide to selfinsure for a significant amount and only purchase "excess" insurance when liability exceeds a specific ceiling. Therefore, in practice there may be a combination of self-insurance and liability insurance, where the self-insurance can take the form of a deductible. This follows the literature which holds that still exposing the insured partially to risk can be considered as a means of controlling moral hazard. ${ }^{15}$

Self-insurance, as described above, obviously has the advantage that it is probably a lot less costly than systems of risk distribution, especially if risks are shifted to an insurance undertaking. The amount paid (via a premium or a contribution) by the risk averse potentially responsible party to have risk removed from him might often be much higher than the actuarially fair value of the risk. Thus one can understand why potentially responsible parties might want to self-insure and only purchase excess insurance for high amounts.

\subsection{Limits and possibilities of self-insurance}

However, there are certain risks and disadvantages with self-insurance as well. One obvious point is that victims should still have the guarantee that a potentially responsible party who is found liable will also be able to pay the compensation. Self-insurance is not necessarily a watertight guarantee against insolvency. This is only the case if regulation could guarantee that the money set aside for covering environmental damage is only to be used for that specific goal. In addition, risk-spreading via systems such as (liability)

15 See S. Shavell, “On moral hazard and insurance”, Quarterly Journal of Economics, 1979, pp. 541-562. 
insurance or pooling has the major advantage that risk-spreading on the basis of economies of scale is possible. A pool or insurer may bring together similar but unrelated risks and can thus increase the expected utility of all insured by reducing risk aversion. The major benefit of insurance or pooling, which is risk-spreading, is obviously lost with self-insurance. Moreover, insurance or pooling systems may have the advantage that specialized insurance undertakings (or brokers) may acquire accurate information on the risk and could thus, via the insurance policy provisions, require specific preventive measures from the potentially responsible parties. Efficient insurance policies may lead to a reduction of the dangers caused by systemic risks, if adequate risk differentiation is performed. ${ }^{16}$ All these advantages are lost with self-insurance. Finally, self-insurance of a responsible party can potentially lead to redistribution problems. Assume that a potentially responsible party does not purchase liability insurance (or any other form of financial security). In that case he would simply run the risk of having to pay major amounts as a result of liabilities and would then as a result of his insolvency pass on the costs to the taxpayer. This externalization of the risk is precisely the problem which will occur as a result of insolvency. This insolvency risk therefore constitutes one of the major arguments in favour of compulsory insurance. ${ }^{17}$

In sum: self-insurance may be a low cost and useful instrument which may allow assets to be set aside (reserves made) to cover future losses. However, in order to avoid the risk of externalization of harm (as a result of insolvency) self-insurance can only be considered an effective financial security if guarantees can be provided through regulation that the reserves set aside will effectively be used for the potential losses for which they are meant. Moreover, the basic problem remains that potentially responsible parties may cause losses which can largely outweigh even the assets which they might have set aside in reserve (under so-called self-insurance). Hence, additional mechanisms will still have to be examined to provide adequate coverage for damage caused through larger risks.

\section{First-party versus third-party insurance}

\subsection{Introduction}

Many legal scholars have indicated that there is a seemingly expanding scope of liability for all kinds of risks. ${ }^{18}$ This can be a cause of great concern for liability insurers. More particularly, elements such as the shifting of the risk of causal uncertainty and the retrospective effects of new liability rules are considered to be potentially dangerous for

16 The case for risk differentiation has been made by G. Priest, "The current insurance crisis and modern tort law", Yale Law Journal, 1987, pp. 1521-1590; S. Bohrenstein, "The economics of costly risk sorting in competitive insurance markets", IRLE, 1989, pp. 25-39 and W.P.J. Wils, "Insurance risk classifications in the EC: regulatory outlook", Oxford Journal of Legal Studies, 1994, pp. 449-467; and, with an application to environmental insurance, K. Abraham, "Environmental liability and the limits of insurance", Columbia Law Review, 1988, Vol. 88, pp. 949-951.

17 See P.J. Jost, "Limited liability and the requirement to purchase insurance", International Review of Law and Economics, 1996, pp. 259-276 and M. Polborn, "Mandatory insurance and the judgment-proof problem", International Review of Law and Economics, 1998, pp. 141-146.

18 See M. Faure and T. Hartlief, "Towards an expanding enterprise liability in Europe? How to analyse the scope of liability of industrial operators and their insurers", Maastricht Journal of European and Comparative Law, 1996, pp. 248-250; and see specifically for environmental liability, M. Faure and D. Grimeaud, "Financial assurance issues of environmental liability", in M. Faure (ed.), Deterrence, insurability and compensation in environmental liability. Future developments in the European Union, Vienna, Springer, 2003, pp. 68-122. 
liability insurers. ${ }^{19}$ An interesting effect of this expanding scope of liability is that both insurers and industrial operators have been looking for alternatives to liability insurance especially to cover larger risks. Several alternatives have been developed, from the use of capital markets (discussed above) to the installation of compensation funds (to be discussed below). ${ }^{20}$

There is one particular alternative, which merits a closer look. It concerns more particularly the tendency in some countries to move away from third-party liability insurance towards first-party insurance. It is precisely this tendency that we would like to examine more closely in this paper. The reason is that this change from third-party towards first-party insurance seems at first blush to correspond nicely with George Priest's suggestion that this would be an appropriate remedy for the American insurance crisis. ${ }^{21}$ First-party insurance would better enable risk differentiation. Some insurers seem to have taken Priest's warnings for a liability crisis seriously and the same is apparently true for the remedies he proposed. One can, especially in the environmental sphere, notice an increasing tendency towards first-party insurance. This is, by the way, not only the case in the environmental area, but also for many other risks. This concerns for instance the areas of occupational health and medical malpractice, and an increasing use of first-party insurance is even also discussed in the traffic accident area. Therefore, this phenomenon definitely merits a closer look. ${ }^{22}$

In this section I will first of all look at the theoretical differences between first-party and third-party insurance. The question arises how, at least in theory, the two differ as far as their ability to prevent risks is concerned as well as the possibility to provide adequate compensation to accident victims. Then I will take a practical example of one systemic risk, environmental harm. The reason is that in the Netherlands Dutch insurers decided to more or less abolish environmental liability insurance and radically change towards environmental damage insurance. I will have a critical look at this change and examine whether this constitutes an example which should be followed for other risks. The question obviously arises why certain risks would be insurable in a first-party insurance scheme whereas they would not be insurable under liability insurance.

\subsection{First-party versus third-party insurance: theoretical differences}

\subsubsection{Introduction}

In the economics of accident law and insurance the reasons why persons seek insurance coverage have been explained. The utilitarian approach with respect to insurance has demonstrated that risk creates a disutility for people with risk aversion. Their utility can be increased in case of loss-spreading or if the small probability of a large loss is taken away

19 See M. Faure, "Causal uncertainty, joint and several liability and insurance”, in H. Koziol and J. Spier (eds.), Liber Amicorum Pierre Widmer, Vienna, Springer, 2003, p. 79-98.

${ }^{20}$ For a nice overview of alternatives see J.R. Tyran and P. Zweifel, "Environmental risk internalization through capital markets (Ericam): the case of nuclear power", IRLE, 1993, 431-444; M. Radetzki (Note 2 above), pp. 180-195.

21 G. Priest, "The current insurance crisis and modern tort law", Yale Law Journal, 1987, pp. 1521-1590.

22 For further comments on this evolution from third-party to first-party insurance for environmental damage see M. Faure, "Environmental damage insurance in theory and practice", in T. Swanson (ed.), An introduction to the law and economics of environmental policy: issues in institutional design, Amsterdam, JAI, 2002, pp. 283-328. 
from the injurer in exchange for the certainty of a small loss. ${ }^{23}$ The latter is of course exactly the phenomenon of insurance. The risk-averse injurer has a demand for insurance; he prefers the certainty of a small loss (the payment of the insurance premium) whereby the probability of a larger loss is shifted to the insurance company, thereby increasing the utility of the injurer. ${ }^{24}$ It is remarkable that in this utilitarian approach of insurance, liability insurance is in the first place regarded as a means to increase the utility of a risk-averse injurer, not so much as a means to protect victims, as is sometimes argued by lawyers.

The reason an insurance company can take over the risk of the injurer is well known: because of the large number of participants the risk can be spread over a larger group of people. The insurer only has to pay attention that he builds relatively small risk groups in which the premium is as far as possible aligned to the risk of the members of that group.

In addition to this utility-based theory of insurance, which sees insurance as an instrument to increase the expected utility of risk-averse persons through a system of riskspreading, Skogh has powerfully argued that insurance may also be used as a device to reduce transaction costs. ${ }^{25}$

Thus one can easily apply these general principles to explain why there will be a demand for liability insurance: it can provide protection for risk-averse injurers. However, it has been argued that several conditions have to be met to keep liability for systemic risk insurable. The question I am interested in within the scope of this section is obviously whether the conditions of insurability might be easier to meet in the case of first-party insurance than in case of third-party insurance. ${ }^{26}$

\subsubsection{Advantages of a first-party insurance scheme}

Liability insurance is a third-party insurance whereby the insurer covers the risk that his insured (the potentially responsible party) will have to compensate a third party. A firstparty insurance is a system whereby the insurance coverage is provided and compensation is awarded directly by the insurer to the victim. Whether such a first-party insurance can be considered as an efficient alternative to third-party liability cannot be answered in general terms. It depends to a large extent on the details of the system and more particularly on whether or not the first-party insurance is combined with the liability of the potentially responsible party.

The underlying principle in first-party insurance is that the insurance undertaking, in principle, pays as soon as damage occurs, provided that it can be proven that the particular damage has been caused by the insured risk. Payment by the insurance undertaking occurs irrespective of whether there is liability. The arguments advanced in the literature in favour of first-party insurance are that the transaction costs would be lower and that risk differentiation might be a lot easier. ${ }^{27}$ The reason is simply that with first-party insurance the insurer covers directly the risk of damage with a particular victim or a particular site. The

23 See K. Arrow, Aspects of the Theory of Risk-Bearing, Helsinki, Yrjö Jahnssonin Säätiö, 1965, and K. Borch, "The Utility Concept Applied to the Theory of Insurance", The Astin Bulletin, 1961, pp. $245-255$.

24 See S. Shavell, Economic analysis of accident law, Cambridge, Harvard University Press, 1987, p. 190.

25 G. Skogh, "The transactions cost theory of insurance: contracting impediments and costs", Journal of Risk and Insurance, 1989, pp. 726-732.

26 This has also been strongly advocated by L. Bergkamp, Liability and environment, The Hague, Kluwer, 2001 , pp. $150-152$.

27 This argument is, again, especially advanced by G. Priest, "The current insurance crisis and modern tort law", Yale Law Journal, 1987, pp. 1521-1590. 
idea is that it is therefore much easier for the insured to signal particular circumstances, which may influence the risk to the insurer. The problem with liability insurance is that the insurer is always insuring the risk that his insured (the potential injurer) will harm a victim (a third party) of which the properties are unknown ex ante to the insurer. Moreover, under liability insurance there are lots of uncertainties, e.g. how the judge will interpret this specific liability of the insured. In the ideal world of first-party insurance the insurer directly covers the victim, and thus the risk. He can therefore monitor directly the risk and in principle provide a much better risk differentiation. ${ }^{28}$

If one takes the importance of risk differentiation and the risks of adverse selection as seriously as Priest did, the shift towards first-party insurance seems to be most promising. One can, at least theoretically, understand why first-party insurance would be beneficial to insurers: it is obviously much easier to control and assess ex ante the risk that a particular victim would suffer damage instead of assessing the risk that his insured potential injurer would cause harm to a third party and would thus be found liable. There are indeed many more uncertainties in third-party liability, which make an adequate risk differentiation more complex. Within liability insurance, risk differentiation is possible as well, in the sense that the insurer can adequately monitor whether his insured is a good or a bad risk (e.g. in the sense of taking preventive measures), which could then be rewarded with a lower or higher premium. But even if an ideal risk differentiation were applied, there are still many uncertainties in liability insurance. For instance, it will depend on the state of case law and the interpretation by judges whether the insured potential injurer will be found liable for a specific behaviour and a specific damage; it is apparently especially this uncertainty caused by judges, which the insurers dislike. Moreover, with third-party liability insurance it is ex ante not possible to know whether the insured injurer will cause damage to a very highincome or a very low-income victim. That type of uncertainty can of course be avoided under first party insurance where, at least in the ideal situation, the victim chooses ex ante the insurance coverage he wishes according to his own demand and expected losses.

Notwithstanding these theoretical advantages, several questions still remain. More particularly the question arises how this scheme could be used to enhance the insurability of particular risks. I will illustrate these questions by focusing on the example of environmental risks. ${ }^{29}$

\subsubsection{Direct insurance for environmental risks: a few questions}

Let us see how first-party insurance could be used as an alternative for liability insurance to cover environmental risks. Several practical questions will arise.

4.2.3.1 First party versus direct insurance. First-party insurance is based on the principle that the victim seeks coverage directly from the insurer. Such a system can of course hardly

28 Many other law and economics scholars have pointed to the advantages of first party insurance. See e.g. W. Bishop, "The Contract-Tort Boundary and the Economics of Insurance”, Journal of Legal Studies, Vol. 12, 1983, pp. 241-266 and R.A. Epstein, Simple Rules for a Complex World, Cambridge, Harvard University Press, 1995, p. 221 and, in the product liability area R.A. Epstein, "Products Liability as an insurance market", Journal of Legal Studies, Vol. 14, 1985, pp. 645-669.

${ }^{29}$ For further details see M. Faure, "Environmental damage insurance in theory and practice", in T. Swanson (ed.), An introduction to the law and economics of environmental policy: issues in institutional design, pp. $283-328$. 
be applied to its full extent in the environmental sphere. Theoretically, in pure first-party insurance it is the victim who takes out insurance coverage and who therefore also pays the premium. Such a pure first-party insurance scheme would probably not be very practical for environmental risks, unless one imagines industrial operators seeking coverage, for example for the pollution that may occur on their own plant. In that case, the operator would, in firstparty insurance, seek coverage for the damage he may suffer himself. Otherwise first-party insurance would mean that private citizens who fear suffering environmental harm, for example in their garden, seek insurance coverage themselves.

However, there is an alternative which looks like first-party insurance, and which is called direct insurance. In a direct insurance scheme one imagines a potential polluter, for example someone who possesses a particular site seeking insurance coverage providing protection also for third parties who might suffer damage resulting from that particular site.

Such a direct insurance scheme is applied in some countries with respect to occupational health. In that case, an employer, say, would take out insurance coverage on behalf of his employees, who could claim directly on the policy. Under direct insurance the policyholder is not the victim, but the potential injurer is. It is, however, not a liability insurance since the trigger to compensate is no longer liability, but the mere existence of damage.

For the environmental risk one could thus examine both pure first-party insurance, whereby potential victims cover losses themselves, and direct insurance, whereby a potential polluter seeks insurance coverage also to the benefit of a third party (the victim). In practice there may be a combination of first-party and direct insurance, in case a possessor of a particular site from which e.g. soil pollution may occur, seeks coverage both for his own damage and for the damage which may be caused to third parties.

4.2.3.2 Scope of coverage and causation. The main difference between traditional liability insurance and either pure first-party or direct insurance is that the coverage under the latter policies is no longer for liability. Hence, a consequence (and, insurers claim, an advantage) is that liability is no longer required in order to claim on the policy. Traditional insurance would require there to be an "accident". However, it is well known that, given the gradual nature of many pollution cases, these can hardly be considered to be sudden events, typical accidents. Therefore, in environmental insurance proof of damage will probably suffice to obtain coverage. It thus remains important to describe clearly what constitutes an insured damage which may give rise to a claim on the policy.

Depending on how this is formulated in the policy, the insured will have to claim that his damage is caused by the insured activity. If there was direct insurance which benefits third-party victims, problems could arise in case of multiple causes. In that case the victim will obviously have to claim and prove that his damage was caused by the particular insured risk.

However, with environmental damage insurance causation does not seem to be a major problem (other than that it may always be a problem in any environmental liability case as well). This is different in cases where first-party insurance solutions are presented for health damage, such as in case of medical malpractice or for occupational diseases. In all of those cases the difficulty will be that the question will have to be settled as to whether the personal injury suffered by the victim is actually caused by medical malpractice or by an occupational disease. These types of causation issues, related to the fact that it should be clear that the harm is caused by the insured risk, may arise also in environmental insurance, but they seem less serious than in cases where personal injury is insured. 
4.2.3.3 Financing. Although less interesting from a theoretical perspective, a practical question that will always arise at the policy level is who should pay for a first-party or direct insurance scheme. A consequence of a pure first-party system is that it is theoretically the victim who seeks insurance coverage himself and who therefore finances the first-party insurance. To the extent that this victim is also the industrial operator who caused the risk, polluter and victim will be the same and it will effectively be the polluter who finances the insurance. If, however, one were to adopt a first-party insurance scheme for "innocent" victims, politicians would probably argue that now victims are forced to finance e.g. the clean-up of the polluted soil in their own garden (by paying the premium for the first-party insurance) whereas the polluter should pay for this. The answer would obviously be that if the first-party insurer of the "innocent" victim were allowed a right of redress against the polluter, the polluter pays principle would still be satisfied and the polluter would still be given appropriate incentives for prevention.

However, it is most likely that at the policy level discussions would primarily go in the direction of direct insurance, since under such a system the polluters finance the insurance coverage for the damage caused to third-party victims as well.

4.2.3.4 Prevention. The next question is how polluters are given appropriate incentives for prevention of environmental harm if the risk is fully covered under insurance. The answer here is that this poses no difference from traditional liability insurance. All insurance systems are potentially vulnerable to the well-known moral hazard problem. ${ }^{30}$ Adequate risk differentiation can be the appropriate remedy to moral hazard. First-party and direct insurance schemes were advanced precisely because they would enable a better risk differentiation. If that were the case, they could even lead to better results as far as prevention is concerned.

In practice, risk differentiation under first-party and direct insurance would mean that e.g. if a particular site were insured, the insurer would use all the ex ante monitoring and ex post devices to check the "ecological reliability" of the particular operator, which should provide optimal incentives for prevention. Hence, if the theoretical possibilities of risk differentiation are used in an optimal manner, first-party or direct insurance schemes should cause no problem as far as prevention is concerned.

4.2.3.5 Relationship to liability law. An interesting issue, since liability is no longer the trigger for coverage, is of course the relationship to liability law. In many instances where first-party or direct insurance schemes are advanced (such as in the areas of medical malpractice and occupational health), those schemes are often supposed to totally replace the liability system. One can see e.g. in the area of occupational health in many European systems a direct insurance scheme (providing coverage to all insured employees of one employer) with an employer's immunity from liability, except in case of intent or gross negligence. In many countries these insurance systems are embedded in social security law.

A traditional argument, e.g. in the area of medical malpractice, against first-party (patient) insurance schemes and in favour of tort law is that the incentives of the health care

30 See G. Wagner, "Versicherungsfragen der Umwelthaftung", in M. Ahrens and J. Simon (eds.), Umwelthaftung, Risikosteuerung und Versicherung, Berlin, Erich Schmidt Verlag, 1996, pp. 104-105 and S. Shavell, “On Moral Hazard and Insurance”, Quarterly Journal of Economics, 1979, pp. 541-562. 
provider would be diluted without a liability system. ${ }^{31}$ At the theoretical level there would be no reason to grant immunity to the injurer even if e.g. a mandatory first-party or direct insurance scheme were introduced. Even if a third-party victim were compensated by the insurer, it would still be possible to use liability law (via the right of recourse) to provide appropriate incentives for prevention and obtain full coverage. ${ }^{32}$ Therefore, there seems to be no reason to let a first-party insurance scheme replace liability law.

Notwithstanding this theoretical starting point, one can often see in practice that firstparty or direct insurance schemes are only accepted (that is to say their mandatory introduction) if e.g. in the area of occupational health the potential injurer (the employer) receives some kind of "compensation" in the form of a partial immunity from liability.

4.2.3.6 Guarantee of coverage. Finally one could ask to what extent a first-party or direct insurance scheme can provide a guarantee that funds will indeed be available at the crucial moment when they are needed, e.g. when a polluted soil needs to be cleaned up. This question has important policy implications and has several different aspects. First of all, it relates to the question whether such a first party or direct insurance scheme should be introduced compulsorily. Indeed, the market could work out wonderful insurance devices, but if no operator made use of them, there would still be no guarantee that, given the insolvency risk, funds would effectively be available when they are needed. However, that is obviously not a particular problem of first-party insurance, but a more general problem relating to the question whether at the policy level a duty to seek financial coverage for environmental risk should be introduced. An issue, which is related to direct insurance, is whether one can provide for a direct right of action for a third-party victim. This concerns those situations where the insurance policy of the industrial operator provides that his coverage also extends to damage caused to third parties. Normally these third parties do not, given the privity of contract, have a claim on the insurance policy, unless they are formally made third-party beneficiaries of the policy, which provides the direct insurance. The question thus arises whether one can see those third-party beneficiary clauses in practice.

After having identified the potential benefits and several points of detail relating to first-party and direct environmental insurance, let us now look at how these new policies are introduced in practice.

\subsection{Environmental damage insurance in practice: the Dutch example}

\subsubsection{A trend towards first-party coverage}

At the end of the last section I indicated that although first-party insurance might seem very attractive at first sight at the theoretical level, since it might better enable a narrowing of risk pools, still a lot of questions arise, especially in its application to environmental risk. It is probably best to examine these questions by looking at a practical example where firstparty insurance of polluted sites has been implemented.

Before doing so it is probably important to stress that this exposé on first-party insurance is not merely theoretical, but does indeed have a certain practical relevance.

31 See, e.g., P. Danzon, "Alternative liability regimes for medical injuries", GPRI, 1999, pp. 3-22 and H. Koziol, "Die Arzthaftung im geltenden und künftigen Recht", in Haftungsrechtliche Perspektiven der Ärztlichen Behandlung, Linz, Universitätsverlag Rudolf Trauner, 1997, pp. 21-35.

32 Indeed, first-party and direct insurance schemes might not always provide a full coverage of losses. 
Indeed, the general liability committee of the Comité Européen des Assurances ("CEA") has carried out a study of first-party legal obligations for clean-ups and corresponding insurance covers in European countries. ${ }^{33}$ This study shows that although the insurance situation still differs between European countries to a large extent, first-party insurance coverage seems to be available in several Member States. ${ }^{34}$ In one country, the Netherlands, insurers have deliberately chosen to provide coverage of polluted sites on a first-party basis. The idea is that the first-party coverage should replace the traditional environmental liability insurance. Hence, it seems interesting to take a closer look at the insurance situation in the Netherlands.

\subsubsection{Environmental damage insurance in the Netherlands: main features}

The starting point for Dutch insurers was the fact that all the theoretical problems concerning the insurability of environmental liability had also played a major role in Dutch environmental practice. This had to do with the fact that environmental risk is an example of a "long-tail risk", whereby the insurer today could be confronted with events which occurred in a distant past and would lead to liability of the insured now. Insurers held that this generally endangered the predictability of the risk.

This and other problems led the Dutch insurers association to present in 1998 a new product, environmental damage insurance ("MSV"). ${ }^{35}$ This policy has been available now since 1 January 1998 and it takes a revolutionary different approach from traditional environmental liability insurance. ${ }^{36}$

This new environmental damage policy provides for various new elements. First of all, it provides integrated coverage of all environmental damage which occurs on or from the insured site. The prerequisite is that it concerns pollution of the soil or of the water. The new environmental damage insurance will replace the traditional pollution insurance (for sudden pollution) in the $\mathrm{AVB}^{37}$ and the liability insurance of the $\mathrm{MAS}^{38}$ (for gradual pollution).

The whole idea is that this coverage constitutes a direct insurance. In other words, the insured site is insured even when clean-up costs have to be made on the site of a third party. Coverage takes place as soon as the insured site is polluted as a result of the insured risk, irrespective of whether the insured could be held liable for the damage or not. In some cases the third party (the victim), moreover, receives a direct action on compensation on the basis of the environmental damage insurance policy. The trigger for compensation under this policy is therefore no longer tort law, but the insurance policy as it has been concluded between the insured and the insurance company. This is therefore typically first-party insurance or, as it is called in the Netherlands, direct insurance. It is direct insurance to the

33 CEA, Study on first party legal obligations for clean-ups and corresponding insurance covers in European Countries, Paris, CEA, 21 October 1998.

34 See the summary tables in the CEA study, p. 32.

35 Milieuschadeverzekering.

36 For a good description of the new policy see J.H. Wansink, "Verzekering en milieuschade als gevolg van vervoer/opslag van gevaarlijke stoffen”, Tijdschrift voor Milieuaansprakelijkheid, 1999, pp. 77-82 as well as C.A. Janssen, "Aansprakelijkheid voor milieuschade en financiële zekerheid naar toekomstig recht: nieuwe oplossingen. Nederlands Recht” in L.F. Wiggers-Rust and K. Deketelaere (eds.), Aansprakelijkheid voor milieuschade en financiële zekerheid, Die Keure - Vermande, 1998, pp. 111-112 and P.J.M. Drion, "Milieu onder één dak: milieuschadeverzekering (MSV)", Verzekeringsrechtelijke Berichten, 1998/2, pp. 19-21. For a critical analysis see also M. Faure and T. Hartlief, "De MSV tegen het licht gehouden", AV\&S, 2001, pp. 141-149.

37 Aansprakelijkheidsverzekering Bedrijven (liability insurance for companies).

38 Milieu-aansprakelijkheidsverzekering Samenwerkingsverband (environmental liability pool). 
extent that it also benefits third parties. It is indeed not the third-party victim who purchases insurance (although the insured may be the victim), but someone who has responsibility for a site on or from which water or soil pollution may occur. The policy benefits third parties as well, at least when this is provided for in the policy.

The environmental damage insurance cannot set aside tort law, but the main advantage according to Dutch insurers is that the coverage is not triggered on the basis of liability. The advantage from the victim's point of view is that coverage can be provided more rapidly and probably at lower transaction costs than through the court cases which are necessary as a result of liability law.

Environmental damage insurance as provided by the Dutch Insurers Association has several categories with different policies. The insured can opt for various coverages. This shows that first-party insurance does indeed better enable an optimal risk differentiation since every insured will be able to purchase insurance coverage according to his own preferences. The damage to the insured location itself is always covered. This at least provides coverage for clean-up costs and this is rather broadly defined. Also costs for the repair of damage are included. Soil pollution, which is also envisaged, falls within the environmental damage insurance. Note, however, that under this policy only the costs of "clean-up" are covered. ${ }^{39}$ Also the damage caused from the insured site and suffered by third parties is covered. This provides a broader scope of protection.

The insured remains in principle fully liable, although the third party (beneficiary) that would be protected under the new MSV policy could claim directly on the policy and would hence in principle not have any interest in using liability law. However, it might be that the insured's coverage was too limited and in that particular case the third party would still (have to) use liability law. In that case the liability itself is not covered (and an insolvency risk remains), but the MSV policy provides for legal aid assistance in a couple of specific cases. ${ }^{40}$ This is the case e.g. if the sum which is insured under the MSV coverage is not sufficient e.g. to pay for the clean-up costs incurred by the government, or if a third party chooses liability law instead of direct action under the MSV policy. ${ }^{41}$

The main feature of the new environmental damage insurance provided in the Netherlands is that it is no longer liability insurance, but only first-party (or direct) insurance. The advantage for the insurer (and for the insured) is that the difficult road of liability law is excluded. Whether liability law will still be used is uncertain. Third parties could still use liability law, although it seems easier for victims to use the direct action provided under the MSV policy. There is, however, one important weakness, which unavoidably remains, the fact that environmental damage insurance is not compulsory. Hence, there may remain situations where companies in the Netherlands have purchased no insurance coverage at all or situations where a basic coverage was taken out for damage on the particular site, but only to a limited extent for damage to third parties. ${ }^{42}$ In those cases, third parties claiming against the responsible party might still be confronted with an

39 Article II.1.1. defines as the scope of coverage: "Insured are the costs of remediation of the insured site. This remediation must apply to a pollution which is the direct and exclusive result of an emission, caused by one of the insured risks ...".

40 This legal aid coverage, however, is not applicable if the insured took a low amount of coverage.

41 See J.H. Wansink, "Verzekering en Milieuschade als gevolg van vervoer/opslag van gevaarlijke stoffen", Tijdschrift voor Milieuaansprakelijkheid, 1999, p. 81.

42 In principle damage caused from the insured site to third parties is always covered, but the amounts of coverage may be limited. 
insolvent polluter. Moreover, the new MSV regime is exclusive, meaning that the coverage for (sudden) soil and/or ground water pollution has now been removed from the liability insurance policy. This means that if an insured has, for example, only taken out MSV coverage for the insured site and a loss occurs to a third party on another site, this third party would probably use liability law against the polluter. In that particular case the polluter cannot call on his general liability insurance ("AVB") since the environmental risks have now been completely removed from that policy as a result of the MSV entering into force. ${ }^{43}$

But that can hardly be considered a weakness of the system of first-party insurance: the insured gets only what he pays for. Since the MSV is a general policy with a lot of options for the insured, premiums and amounts of coverage can vary. The type of costs which are insured are, however, identified in the general policy and according to the CEA study on first-party insurance the total amount of coverage available under this new environmental damage insurance in the Netherlands would be $€ 11,344,505.40$.

\subsubsection{Evaluation ${ }^{44}$}

This section has considered a new environmental insurance product introduced recently in the Netherlands, which is gaining popularity in other countries as well. ${ }^{45}$ The reason for devoting so much attention to this new product, referred to as environmental damage insurance, is that the insurers claim that many of the problems that arise when insuring environmental risk are in fact problems related to environmental liability. In other words, they claim that the environmental risk would be better insured if the risk could be insured on a first-party basis. Many of the problems that appear under liability insurance would then disappear, or at least be reduced, so it is held.

From a theoretical perspective the Dutch insurers certainly have a point: already in 1987 George Priest claimed that the American liability and insurance crisis was caused by a shift from first-party to third-party insurance. The obvious remedy for him was then to move back from third-party (liability) insurance to first-party insurance. In reality the first-party model does seem an appropriate remedy for problems in liability cover, but in fact only for just one aspect of the insurability of the environmental risk, the issue of risk differentiation. Indeed, first-party insurances are held to enable better risk differentiation than traditional liability insurance. This is an important issue since adequate risk differentiation has always been advanced as the appropriate remedy for the dangers of moral hazard and adverse selection. But, on the other hand, other problems concerning the insurance of (environmental) risk will remain, for instance the issue of limited capacity in case of catastrophic accidents, the risk of judges shifting causal uncertainty to an industrial operator, and the

43 J.H. Wansink, "Verzekering en Milieuschade als gevolg van vervoer/opslag van gevaarlijke stoffen", Tijdschrift voor Milieuaansprakelijkheid, 1999, pp. 81-82.

44 See for a critical evaluation also M. Faure, "Environmental damage insurance in the Netherlands", Environmental Liability, 2002, pp. 31-41 and M. Faure and T. Hartlief, "De MSV tegen het licht gehouden", $A V \& S, 2001$, pp. 141-149.

45 Ranson reports that also in Belgium a "direct" environmental insurance may be offered which would also cover gradual pollution (but would exclude ecological damage). See D. Ranson, "Verzekering van milieuaansprakelijkheid", Milieu- en Energierecht, 2000, p. 68. The new policy would cover, like the Dutch example, remediation costs. It would be offered by AIG and would provide coverage up to about 25 million euros (see $\mathrm{H}$. Kerremans, Aansprakelijkheid voor Milieuschade en verzekeringsmogelijkheden in Milieuzorg in de Onderneming, I. Juridische, fiscale en organisatorische aspecten, Antwerpen, Standaard, pp. 537-583). 
danger of retrospective application of liability laws. Indeed, also under first-party insurance, capacity will not be unlimited; first-party insurance also requires a condition of causation (it must be proven that the damage was caused by the insured risk) and the problem of retroactive liability resulting from the "long-tail" character of the environmental risk may be solved both under third-party and under first-party insurance (at least to some extent) by the introduction of a claims-made cover. ${ }^{46}$

The Dutch insurers introduced their new environmental damage insurance with great enthusiasm, claiming that they have now been able to increase the manageability and predictability of the risk. Their basic idea is that it is much easier to monitor and predict the potential of damage ex ante with one particular site, than to predict the chances that one operator may be held liable to pay damages to a third party. One important factor of uncertainty (the judge) has thus been excluded. Although one can understand the enthusiasm of the insurers and, to some extent, the corporate world (since under firstparty insurance they also receive coverage for their own losses) there are clearly disadvantages as well. The major disadvantage is not related at all to the fact that the first-party environmental damage insurance would not be an adequate insurance product, but to the fact that the introduction of this new product was accompanied by the abolition of liability insurance for the environmental risk. As a result of this, some victims may no longer receive compensation, at least in those cases where the damage insurance does not provide sufficient coverage and the polluter is insolvent. Therefore, at the policy level this raises the question whether it might not be necessary to introduce a compulsory insurance scheme, ${ }^{47}$ be it liability- or first-party-based. Given the risk of insolvency, a serious problem of underdeterrence could arise which could be solved by introducing some obligation to provide financial security to cover the environmental risk. In addition, the fact that the Dutch insurers are collectively moving from liability to environmental damage insurance raises questions concerning competition on the insurance market.

Finally, it should be mentioned that the type of first-party/direct insurance discussed in this section has little to do with the no-fault accident compensation schemes as they exist in e.g. Sweden and New Zealand. These are more public compensation systems whereby victims receive compensation either via an insurance or a public-funding mechanism irrespective of the fault of an injurer and often also irrespective of their own behaviour. It is not possible within the scope of this paper to discuss these mechanisms here, but they fit more into either compensation funds (which will be discussed in section 7) or social security schemes. ${ }^{48}$ For now it should only be remembered that we merely discussed here first-party and direct insurance schemes as initiated by insurers.

46 See W.J. Richardson, "Financial institutions for sustainability”, Environmental Liability, 2000, pp. 52-64; M. Katzman, "Pollution liability insurance and catastrophic environmental risk", Journal of Risk and Insurance, 1988, p. 88 and J. Spier and O.A. Haazen, Aansprakelijkheidsverzekeringen op claims-made grondslag, 1996.

47 For a similar argument see A. Monti, "Environmental risk: a comparative law and economics approach to liability and insurance", European Review of Private Law, 2001, p. 65.

48 See on the working of these schemes and the difference with traditional tort law and insurance, M. Faure, "The applicability of the principles of private insurance to social healthcare insurance seen from a law and economics perspective", GPRI, 1998, pp. 265-293 and M. Faure and T. Hartlief, "Social security versus tort law as instruments to compensate personal injuries: a Dutch law and economics perspective", in U. Magnus (ed.), The impact of social security law and tort law, Vienna, Springer, 2003, pp. 222-265. 


\section{Risk-sharing agreements}

\subsection{Risk-sharing by operators: principles}

Pooling is often discussed as a means of increasing the capacity of insurance. In that respect reference is usually made to the pooling of insurers as a tool to provide higher amounts of coverage. ${ }^{49}$ In the long run pooling may have possible negative consequences. If pools act like monopolistic insurers, premiums might be relatively high and unattractive for specific operators.

An alternative is to think about risk-pooling by plant operators. Faure and Skogh have proposed risk-pooling by operators, a risk-sharing agreement as an alternative compensation scheme which could provide higher amounts of coverage to deal with the nuclear risk. ${ }^{50}$ Their reasoning, which can also apply to increase capacity for environmental risks, is as follows.

Although large risks may be uninsurable on the traditional insurance market, these large risks might be shared by ex ante agreements. Those ex ante agreements are often used in cases where the risk is uncertain and possibly difficult to estimate, at least initially before information on the probability and possible magnitude of the accident is available. The risksharing could be realized through an international convention in order to get as many plantowners involved as possible. It could, however, also function within the existing conventions on a voluntary basis. The risk-sharing agreement would function according to the following principles:

- The owner of a nuclear power plant is strictly liable for losses caused by an accident, including third-party liability.

- In principle, strict liability should be unlimited. It may, however, be necessary to limit initially the liability to e.g. U.S.\$ 100 billion, which would already be substantially larger than the size of the liability today. This would also allow for compensation for medium-size accidents.

- Every plant-owner should contribute to a mutual guarantee fund. This mutual pool covers the liability in case of an accident. If there are 100 nuclear power plants involved in the pool, and thus 100 members, each plant-owner then has to contribute U.S.\$ 1 billion in case of an accident with costs rising to U.S.\$ 100 billion.

- The maximum potential claim on each plant is therefore U.S.\$ 1 billion. This makes reinsurance necessary. The international insurance market can provide a fraction of the desired coverage; another part can be obtained through reinsurance from the states.

A major difference with the existing system is that, in the proposed risk-sharing agreement, all plants share the costs of accidents wherever they occur in signatory states. This makes nuclear safety a collective economic responsibility for the industry. The liability is to a large extent transferred from the single plant-owner to the collective guarantee fund mutually owned by the nuclear industry in the contracting states. The mutual fund will face moral hazard problems caused by the individual members. It will therefore be in the interest

49 See further M. Faure and T. Hartlief, Insurance and expanding systemic risks, pp. 90-94.

50 See M. Faure and G. Skogh, "Compensation for Damages Caused by Nuclear Accidents: A Convention as Insurance”, GPRI, 1992, pp. 499-513. 
of the fund to control its members and to reduce risks, for instance by imposing requirements before being accepted as a member. Hence, the industry will be forced to take preventive measures by the mutual fund as a condition of being accepted as a member.

Thus an important effect of this risk-sharing agreement would be that accident prevention would gain a new economic dimension. Unlimited liability of plant-owners in combination with a mutual guarantee fund will create a collective interest in the industry in reducing risks and controlling pool members.

The working of this ex ante agreement can be illustrated by one example. Assume, for instance, that there is an accident in France that causes U.S.\$ 60 billion damage in France, Belgium and Germany. Each of the 100 plant-owners will then contribute U.S. $\$ 600$ million. The 12 plants in Sweden would have to cover U.S.\$ 7.2 billion of losses. A large part of these costs would be insured by the insurance market (and maybe by the existing nuclear insurance pools) and there would be reinsurance by the states and to some extent by the international insurance market. The possibility of reinsurance by the state is already covered under the Paris Convention. For instance in the Netherlands, the Dutch state provides for a guarantee of almost U.S.\$ 3 billion. This illustrates that although it might be impossible to receive insurance coverage up to U.S.\$ 1 billion for each plant, an ex ante commitment by each power plant to intervene in the costs of a nuclear accident up to a maximum of U.S.\$ 1 billion might well be given if it is supported by insurance, reinsurance and a state guarantee.

\subsection{Risk-sharing agreements: examples}

\subsubsection{The Price-Anderson Act}

The implementation of such a risk-sharing agreement should not be considered at all impossible for several reasons. In this respect we can point to the fact that a comparable, although not completely identical, system has been introduced by the most recent amendment to the U.S. Price-Anderson Act. The principle in U.S. law is still individual liability of the operator of the power plant up to an amount of U.S.\$200 million, ${ }^{51}$ for which the operator will seek insurance coverage with the classic nuclear insurance pools. If the damage is higher than U.S.\$200 million all nuclear power plants in the United States will share on a pro rata basis for the 114 American power plants up to U.S.\$ 7.2 billion. ${ }^{52}$ The amounts have meanwhile been increased so that the total now comes close to U.S.\$ 9 billion. ${ }^{53}$ This American example shows that through risk-spreading between all nuclear power plants considerably higher amounts can be made available than with a liability limit which is set on the basis of the insurability of the risk by a national insurance pool. ${ }^{54}$

51 See M. Trebilcock and R. Winter, "The economics of nuclear accident law”, IRLE, 1997, p. 221.

52 See, for a description of the American system, J. Marrone, "Closing the Circle of Protection for the Public-the Evolution of the System in the United States", paper presented at the symposium Nuclear accidentsliability and guarantees, Helsinki, Finland, September 1992; F. Heimann, "The U.S. Liability Protection System for Nuclear Power Plants", paper presented at the symposium Nuclear accidents, liability and guarantees, Helsinki, Finland, September 1992; M. Robesin, “Aansprakelijkheid voor kernongevallen, ruim een jaar na Tsjernobyl”, MenR, 1987, pp. 228-229 and M. Rowden, J. Kraemer and L. Cuoco, "La révision de 1988 de la loi Price-Anderson ou mieux vaut tard que jamais”, Bulletin de droit nucléaire, No. 42, pp. 79-101.

53 So M. Radetzki (Note 2 above), p. 188. 


\subsubsection{P\&I Clubs}

In other fields of liability, risk-sharing agreements are also well known. For instance, marine oil pollution is insured by the so-called Protection and Indemnity Clubs (P\&I Clubs). The members of these clubs are the shipowners. They provide insurance on a non-profit basis for the members. At the beginning of each year a "call" is made which covers the claims and administrative costs. ${ }^{55}$ These P\&I Clubs function as a mutual insurance company. Profits and losses are shared amongst the members. If the receipts of one year are insufficient to cover the losses, an additional call can be asked from the members.

Obviously such co-operation between commercial undertakings could be viewed as endangering competition, including when it takes place to cover risks. One should note that as far as insurance undertakings are concerned the Exemption Regulation 358/2003 applies. ${ }^{56}$

The pooling by P\&I Clubs had already been exempted previously from the application of the old Article 85(1) EEC Treaty by a Commission decision of 16 December 1985. This individual exemption was criticized in the literature since it was held that the conditions to exempt P\&I Clubs from competition law were not met. ${ }^{57}$ These voices have apparently not convinced the Commission since in the report of 12 May 1999 on the Exemption Regulation it again argues that this co-operation between P\&I Clubs is necessary to offer adequate coverage (although the companies involved together have a market share of 89 per cent). ${ }^{58}$

Anyway this shows that based on this report at least P\&I Clubs should not worry that their anti-competitive pooling strategies will be held to violate European competition law.

\subsubsection{Nuclear liability: developments ${ }^{59}$}

Also within the revision of the Paris and Vienna Conventions, the drafting committees have discussed several alternatives to produce higher amounts of coverage. In this respect a proposal by the delegations of the United Kingdom and France is worth mentioning. They proposed a four-tier system whereby the compensation would be provided as follows:

${ }^{54}$ For an in-depth analysis of the liability regime under the Price-Anderson Act with a comparison with European compensation schemes see T. Vanden Borre, "Dekking van het nucleaire risico op nationaalrechtelijke basis of via internationale verdragen: de Verenigde Staten versus Europa", in K. Deketelaere, M. Faure and G. Verhoosel (eds.), Grensoverschrijdende milieuproblemen: uitdagingen voor de nationale en internationale rechtsorde, 1998, pp. 443-490 and T. Vanden Borre, Efficiënte preventie en compensatie van catastroferisico's. Het voorbeeld van schade door kernongevallen, 2001,pp. 280-290 and 639-674.

55 See J. Bongaerts and A. Debièvre, "Insurance for Civil Liability for Marine Oil Pollution Damages", GPRI, 1987, pp. 145-187; M. Faure and G. Heine, "The Insurance of Fines: The Case of Oil Pollution", GPRI, 1991, pp. 39-54 and T.G. Coghlin, "Protection and Indemnity Clubs", Lloyd's Maritime and Commercial Law Quarterly, 1984, pp. 403-416.

56 See Commission Regulation 358/2003 of 27 February 2003 on the application of Article 81(3) of the Treaty to Certain Categories of Agreements, Decisions and Concerted Practices in the Insurance Sector, OJ, L53/8 of 28 February 2003: this regulation grants, under certain strict conditions, an exemption to the insurance sector of the application of European competition law.

57 See M. Faure and R. Van den Bergh, Objectieve aansprakelijkheid, verplichte verzekering en veiligheidsregulering, 1989, pp. 331-336.

58 Commission report, no. 29.

59 For these developments see also H. Conruyt-Angenent, "L'évolution en droit belge de la réponation des dommages nucléaires à la lumière des conventions internationales", in J. Rogge (ed.), Liber Amicorum René van Gompel, Études en assurances, 1998, pp. 75-108 and T. Vanden Borre, "Recente ontwikkelingen in het nucleaire aansprakelijkheidsrecht: innovatie of renovatie?", Milieu- en Energierecht (MER), 2000, pp. 25-49 and T. Vanden Borre, Efficiënte preventie en compensatie van catastroferisico's. Het voorbeeld van schade door kernongevallen, 2001, pp. 117-141. 
(a) up to the amount provided under the legislation of a contracting party, by insurance or other financial security of the operator liable in accordance with the Vienna or the Paris convention;

(b) between that amount and (A) million Special Drawing Rights, out of funds provided by the operator liable which, subject to $\S 4$ of this article, the operator shall have secured through his membership of a risk pool established by free association of operators;

(c) between (A) and (B) million Special Drawing Rights, out of public funds to be made available by the contracting party in whose territory the nuclear installation of the operator liable is situated;

(d) between (B) and (C) million Special Drawing Rights, out of public funds to be made available by the contracting parties according to the formula for contributions specified in article 5.

The proposal moreover stipulated that the risk pool shall secure the availability of the funds through contracts binding upon all participants and shall allow for the accession of new participants on agreed terms which may take account, inter alia, of risk.

Unfortunately, however, these proposals have not been taken over, neither in the Protocol to amend the Vienna Convention nor in the Convention on Supplementary Funding, both of 12 September 1997. The idea remains that if the damage exceeds the liability of the operator, the state will have to intervene with public funds.

\subsection{Risk-sharing versus insurance}

A pooling of resources by operators might also be a good alternative to providing coverage for larger risks. In that respect the examples of the nuclear area are totally applicable to other catastrophic risks as well. The crucial question is whether the operators themselves are better able to follow the fundamental goals of an efficient system of prevention and compensation. Such a system can only work efficiently to the amount that risk differentiation can be applied. Hence, the crucial question is whether the operators of the pool can estimate the costs of liability claims and can judge, on the basis of actuarial expertise, which potentially responsible parties pose higher liability risks than others. Pooling can only be considered an efficient funding system if the managers of the pool are able to identify the potentially responsible parties who are higher liability risks than others and if they can adjust the contributions to the pooled funding scheme accordingly. If, therefore, there are situations where one can assume that the risk is so technical and complicated that only the operators themselves can be judged able to monitor the risk and to require preventive measures accordingly, a pooling system run by operators might create more efficient results than insurance.

There is, moreover, one other important advantage of mutual risk-sharing via pooling. Skogh has shown that insurance requires pricing to be undertaken before the occurrence of the insured event. An agreement to mutually share each other's losses does not necessarily require the ex ante payment of a premium. Mutual risk-sharing can be based on an agreement to share losses ex post, after the accident occurs and does not require actuarial information ex ante. ${ }^{60}$

60 See G. Skogh, "Development Risks, Strict Liability and the Insurability of Industrial Hazards”, GPRI, 1998, pp. 247-265 and G. Skogh, "Mandatory Insurance: Transaction Costs Analysis of Insurance", in B. Bouckaert and G. De Geest (eds.), Encyclopedia of Law and Economics, 2000, pp. 521-537. 
Mutual risk-sharing seems therefore an ideal solution if the probability of an accident is statistically unpredictable. It is however, also necessary for moral hazard to be controlled via mutual monitoring, e.g. by individuals in the same business. This explains why originally risk distribution started via mutual risk-sharing. Insurance can only develop when actuarial information is available. Hence, mutual risk-sharing, e.g. via pools of operators, seems warranted when precise actuarial information on the predictability of the risk is lacking, as in the case of damage to biodiversity. In other cases one can see the development of risksharing agreements particularly when traditional insurers refuse to cover such risks. This has been the case e.g. in the Netherlands, where traditional insurers consider medical liability within hospitals uninsurable. Hospitals have reacted by creating mutuals, based on risksharing agreements, to cover the risks.

However, one should realize that this is not always necessarily the case. Indeed, insurers are specialized in dealing with risk and so have a good knowledge of risk differentiation. Moreover, the costs of running a pooling system might be high as well. In sum, the question whether a pooling system is more efficient than an insurance scheme will not only depend upon the ability of either the insurers or the managers of a pooling system to monitor the risks involved, but also upon the transaction costs of both schemes. In any event, a pooling system should not be excluded as a tool for providing financial security to cover damage caused by systemic risks. However, if pooling systems are used, the administrative agency should require sufficient guarantees that at the end of the day the pool can meet the obligations of the operators involved. As was shown in the nuclear example, some reinsurance by the pool may be necessary to cope with that issue.

\section{Ex ante guarantees and deposits}

\subsection{Ex ante guarantees and deposits}

Many states in their legislation provide possibilities for operators of classified activities to offer financial security via other means than through liability insurance. The same is true for international conventions which impose on licensees an obligation to secure financial security. To illustrate the wide possibility of financial guarantees I will now take a look at the Flemish example and more particularly at the proposals of the Interuniversity Commission for the revision of the Environmental Law in the Flemish region, ${ }^{61}$ which has set out elaborate provisions concerning financial guarantees.

\subsection{Obligation of financial security: a balanced approach}

The obligation to provide financial guarantees has been provided for in Part 9, dealing with compensation for damage caused by pollution. Chapter 3 of Part 9 specifies in section 1 that the Flemish government shall designate those categories of classified installations and activities for which the permit-holder or the holder of a notification certificate is bound to provide financial guarantees in order to guarantee liability for the damage or for the impairment of the environment which may be caused by his installations or activities. ${ }^{62}$ The

61 This Commission provided a Draft Decree on Environmental Policy with some interesting proposals. See H. Bocken and D. Ryckbost (eds.), Codification of environmental policy. Draft Decree on Environmental Policy, 1996.

62 See the proposed article 9.1.14 of the Draft Decree on Environmental Policy. 
advantage of this system is that there is no general duty for all operators of classified installations to provide financial security. It will be the government or the administrative authorities who decide in which cases financial security is required. However, Article 9.1.14 $\S 3$ of the Draft Decree on Environmental Policy provides that there shall be an obligation to provide financial guarantees in relation to carrying out a soil clean-up activity.

It is interesting that, as far as the nature of the financial guarantees is concerned, Article 9.1.16 of the Draft Decree on Environmental Policy does not only rely on liability insurance, but stipulates that the financial guarantee in question may assume any of the following forms:

- insurance policy;

- guarantee provided by a financial institution;

- any other form of personal or collateral security;

- a deposit paid by way of security on a separate account with the environmental guarantee account.

The amount of the financial guarantee shall be fixed by the Flemish government by means of general, sectoral and integral conditions, in the light of the dangers presented to man and to the environment by various categories of installations and activities. In addition, Article 9.1.17 $\S 1$ stipulates that for each category separate guarantees are provided for (a) damage caused by death or by personal injury, and (b) any other type of damage or impairment to the environment.

The Interuniversity Commission clearly assumed that the amount cannot be mentioned in general terms but will have to depend upon the type of installation. Apparently the Interuniversity Commission also judged it important to provide for specific amounts on the one hand for personal injury and on the other hand for environmental damage.

Article 9.1.22 of the Draft Decree on Environmental Policy also stipulates that the money available under financial guarantee may only be claimed for the purpose of restoring damage or impairment of the environment. This is necessary, as was mentioned above, to avoid the guarantee that might have been set aside to cover environmental damage being used by other creditors.

\subsection{Optional financial caps}

The liability in the Draft Decree on Environmental Policy is in principle an unlimited liability. Hence, the provisions concerning the amounts only concern the amount of financial security. However, the Draft Decree on Environmental Policy introduces the possibility of a system of optional financial caps, which merits further attention.

Part 9 of the Draft Decree of the Interuniversity Commission provides for rules concerning compensation of damage caused by pollution. Title 1 of this Part 9 provides for rules concerning liability and financial guarantees. Within this Title 1, Chapter 4 deals with "Limitation of liability by establishing a voluntary guarantee fund".

Article 9.1.24 of the Draft Decree provides in $\S 1$ that the operator may limit any liability which he may incur pursuant to the provisions of this title for any damage to the environment to the amount which he is bound to provide by way of financial guarantee where he is able to prove that a guarantee fund guarantees compensation for any damage or impairment of the environment exceeding this amount within the limits and subject to specific conditions. The limit only applies when the guarantee fund provided by the operator guarantees compensation over and above the amount for which the operator is anyway liable 
to provide a financial guarantee and reaches specific amounts to be determined by implementing regulations. In addition, the possibility of limitation of liability only applies when the guarantee fund proposed by the operator has been recognized by the Flemish government. When the guarantee fund proves inadequate to pay compensation within the limits, the operator shall have unlimited liability in respect of these amounts. This does not mean that there is unlimited liability, but liability up to the amount established by implementing regulations. ${ }^{63}$ Where there is deliberate fault on the part of the operator, the operator shall continue to have unlimited liability. ${ }^{64}$

The explanatory memorandum ${ }^{65}$ makes it clear that the general rule in the environmental liability regime proposed by the Commission is still unlimited liability. The draft Article 9.1.24 provides only for an optional mechanism which in fact trades limitation of the operator's liability for the guaranteed availability of additional capital for the compensation of victims. Operators already have to provide a minimum financial guarantee for their liability. The proposed Article only offers them the possibility of limiting their personal liability by providing a second, substantially higher amount of guarantees to a compensation fund. (The term "compensation fund", which is used in the Flemish text is somewhat misleading, since it concerns a fund which only serves to compensate the damage caused by this particular injurer.)

Although the text of the Flemish proposal is not clear in every respect, this proposal may well correspond to the economic principles of compensation. A basic financial guarantee will always have to be provided on a mandatory basis by the operator. The draft only concerns the payment of a substantial higher amount as a second layer which constitutes an "optional limitation fund". This additional guarantee may be covered by insurance, which gives the insurer incentives to exercise additional control. The efficiency of the regime will depend upon the expected amount of the damage. But the administrative authority (the Flemish government) can apparently control the amount in every specific case. Thus the government makes a trade-off and accepts the optional limitation fund (for an amount which should in principle be sufficient to cover every loss) which provides a higher certainty of compensation for victims on the one hand and certainty for risk-averse injurers on the other hand. That is the main difference with generalized statutory caps which one can find e.g. in the nuclear liability conventions. These generalized caps are usually judged inefficient because they do not take into account the individual financial situation of the injurer, nor the damage he may cause. ${ }^{66}$ That is different from the individualized optional caps proposed by the Flemish Interuniversity Commission. The advantage for operators in engaging in this regime is that they can limit ex ante their exposure to liability by providing a guarantee for an amount which in principle guarantees to cover all losses. Thus the system also allows for a differentiation of risks and injurers. Moreover, the injurer's incentives will remain unaffected since unlimited liability still applies in case of international fault (Article 9.1.24 §6).

63 See Article 9.1.24, § 5.

64 Article 9.1.24, §6.

65 H. Bocken, D. Ryckbost and S. Deloddere, "Liability and Financial Guarantees", in H. Bocken and D. Ryckbost (eds.), Codification of Environmental Law. Draft Decree on Environmental Policy, 1996, pp. 214-223.

66 See on the inefficiency of these financial caps M. Faure and D. Grimeaud, Note 1 above, pp. 194-206. 


\subsection{Deposits}

In addition to these interesting provisions concerning the voluntary guarantee fund, the Draft Decree on Environmental Policy also contains provisions concerning the obligation to provide deposits. In some cases, the permit-holder may be required to pay a deposit into an environmental guarantee account. Interestingly enough these deposits are held in a separate account for the benefit of the depositor and can only be used to cover expenses related to the treatment they are intended to cover. ${ }^{67}$ When all the obligations have been fulfilled by the permit holder, the deposit and the interests relating thereto have to be repaid to the permitholder. This means that effectively the deposit is the amount of a guarantee that remains at the disposition of the authorities who run the environmental guarantee account and provides proceeds in the form of interest which are returned, for example, when an operation is terminated and no damage has occurred. Title 4 of Part 9 deals in more detail with the environmental guarantee account.

\subsection{A flexible solution}

In sum, this Flemish example shows that there are many more financial techniques available to guarantee financial security concerning the repair of harm than merely liability insurance. The Draft Decree not only refers to guarantees provided by a financial institution, personal or collateral security, but even to deposits paid to an environmental guarantee account. In all of these cases the goal is to ensure that when damage occurs sufficient coverage is available to pay compensation for the damage that the potentially responsible party has caused. All these instruments are, in other words, meant to solve the insolvency problem with the related risks of undercompensation and underdeterrence.

At the policy level the Flemish example is important, since the proposals of the Interuniversity Commission for the revision of environmental law in the Flemish region came into being after long consultations both with the insurance industry and with financial institutions and the industrial world. The idea of providing for deposits in an environmental guarantee account, which could lead to interest payments to the benefit of the industrial operator seemed very attractive to industry, especially if the payments were made taxdeductible. The major advantage is that the payments of deposits into a guarantee account are not lost if an activity is exercised without any damage (hence, it provides excellent incentives for prevention), whereas the premiums paid to an insurance undertaking are obviously lost to industry, even if no damage occurs during a plant's operation.

The Flemish example shows that mandatory financial security can be required on a flexible basis, without the need to jump necessarily to liability insurance. It also shows that it is better to work with flexible solutions where the form and amount of the financial security required is tailored according to the needs of the specific case. This calls for a regulation either for an entire branch or industry or via permit conditions set by administrative agencies, instead of general rules which would lack the flexibility required.

67 See H. Bocken and D. Ryckbost, "Deposits”, in H. Bocken and D. Ryckbost (eds.), Codification of Environmental Law. Draft Decree on Environmental Policy, 1996, p. 224. 


\section{Compensation funds}

\subsection{Introduction}

A question that inevitably arises when issues of damage caused as a result of catastrophic risks are discussed is whether traditional liability law, combined with insurance is at all able to provide for compensation for damage caused by these large risks. Issues of fault or negligence have been avoided in many legal systems by a trend towards strict liability for many larger risks. However, strict liability alone will not of course guarantee compensation, given the insolvency problem, so liability must be supplemented by a system of financial coverage. Many problems may arise, however, with the insurance of catastrophic risks. Therefore in many legal systems the question has been asked whether compensation for damage caused by larger risks should be provided through compensation funds. Wellknown in this respect is, of course, the U.S. Superfund, introduced through CERCLA, which has led to a lot of criticism. ${ }^{68}$ Also in several European legal systems pleas can be heard in favour of installing compensation funds to cover larger risks. In the Netherlands this has been proposed in the literature for environmental damage. ${ }^{69}$ In addition the idea is now increasingly introduced in policy documents in the various European Member States formulating proposals for the reform of environmental law. In this respect we can once more point to the Interuniversity Commission for the Reform of Environmental Law that proposed the introduction of a compensation fund in the Flemish Region, ${ }^{70}$ and also to a Dutch study undertaken on behalf of the Ministry of the Environment proposing the introduction of an environmental compensation fund in the Netherlands. ${ }^{71}$ But the importance of compensation funds is discussed not only in the context of environmental damage, but also with respect to many other larger risks. Think too in this respect of occupational health hazards caused by exposure to asbestos. In many countries, this has led to calls for compensation funds to compensate victims of asbestosis. This was especially the case where the liable employer had gone out of business or was found insolvent. Therefore, there are ample reasons to take a closer look at the phenomenon of compensation funds and to examine their possible function in compensating damage. It is especially important to compare the functions of compensation funds with traditional insurance. ${ }^{72}$

68 Interesting papers analysing Superfund can be found in R.L. Revesz and R.W. Stewart (eds.), Analysing Superfund, Economics, Science and Law, Washington, 1995.

69 See P.A. Kottenhagen-Edzes, Onrechtmatige daad en milieu. Het gebruik van het privaatrecht bij het voorkomen van milieu-aantasting en het verhaal van milieuschade, 1992, 297-298; E. Hulst, Grondslagen van Milieuaansprakelijkheid, 1993; J. Knottenbelt, Produktaansprakelijkheid, 1990 and A.J. Van, Onzekerheid over daderschap en causaliteit, Arnhem, Gouda Quint, 1995, pp. 145-154.

70 See Interuniversitaire Commissie voor de Herziening van het Milieurecht in het Vlaamse Gewest, Voorontwerp Decreet Milieubeleid, 1995, pp. 943-985 and H. Bocken, W. Lambrecht, M. Boes, A. De Nauw, M. Faure and L. Lavrysen, "The Flemish Draft Decree on Environmental Policy: An Outline", in H. Bocken and D. Ryckbost (eds.), Codification of Environmental Law. Proceedings of the International Conference, 1996, pp. 31-32.

71 P. Gilhuis and J. Verschuuren, "Een Milieuschadefonds in Nederland; een Onderzoek naar de Mogelijkheden", Publicatiereeks Milieubeheer, 1994/3. For comments see E. Hulst, "De werkelijkheid rondom een algemeen milieuschadefonds, een commentaar", TMA, 1995, pp. 167-173 as well as De Putter and J. Verschuuren, "Een milieuschadefonds in Nederland?", MenR, 1995, pp. 96-99.

72 See inter alia M. Faure and T. Hartlief, "Compensation Funds versus Liability and Insurance for Remedying Environmental Damage", Review of European Community and International Environmental Law, 1996, pp. 321-326. 


\subsection{The various funds}

One cannot escape the impression that often, especially at the political level, funds are advocated as a miracle solution for all problems of large risks where no clear definition is given of specific funds. This can be misleading, since the term fund is often used for a variety of private or public financial arrangements, some of which have already been discussed in this paper, which may be quite different. We will briefly sketch the kind of funds that might play a role when environmental damage is discussed. This short overview will make clear that very different goals are usually served by these various funds.

\subsubsection{Limitation fund}

In American literature the idea of a fund is sometimes used to refer to the solutions in cases of mass damage caused by similar products or services. The problem that usually arises in these cases of so-called serial damage (e.g. with toxic torts) is that the liable enterprise may be willing to agree to a settlement with the victims on condition that he can offer a certain sum to all the victims in order to reach a final settlement for the damage caused by the specific tort. In a certain sense the manufacturer then raises a fund that will have to be used to compensate all victims. It could be called a limitation fund since the enterprise agreeing to such a settlement usually wishes to limit its liability to the amount paid into the fund. In this case no risk-spreading with other (potential) manufacturers takes place, since only the liable manufacturer finances the fund. Examples of such a limitation fund can be found in the area of civil liability for oil pollution damage. Article V of the Convention of Brussels on Civil Liability for Oil Pollution Damage provides for the possibility for the liable tanker-owner to set up a limitation fund to compensate victims. ${ }^{73}$ As reward for payment of a particular sum the duty to compensate is usually limited to the amount made available: a limitation fund. It has also been argued in the Netherlands that such a fund solution would make compensation for health damage caused by exposure to toxic substances a lot easier. ${ }^{74}$ A problem that will, however, inevitably arise with e.g. environmental damage is latency. It is essential in a limitation fund solution that latecomers are excluded. Therefore this might not be the ideal solution in cases where there may be a long time lapse between exposure and damage. The goal of a limitation fund in these cases is not so much to provide a remedy against e.g. disappearing perpetrators, but to have an adequate instrument to divide the available proceeds among the victims in case of serial damage. $^{75}$

There could thus be a role for such a limitation fund. If one fears that a certain activity may cause harm in the future, at the start of the operation the enterprise involved in the activity could be asked to pay a substantial amount ex ante which would become available if damage resulting from a particular risk occurs. If the damage does occur, the liability would then be limited to the amount the injurer had to pay. As we have just explained above, this

\footnotetext{
73 But in that particular case the liability itself has also been limited. 1996.

74 See the inauguration address of L. Dommering-Van Rongen, Schade Vergoeden door Fondsvorming,

75 This was the reason that the European Directive on Product Liability also incorporated the idea of a limitation fund in Art. 16 which gave Member States the option to limit liability in case of serial damage to an amount which may not be less than 70 million euros. However, only a few Member States have used this option.
} 
regime has been proposed in the Flemish Decree on Environmental Policy. ${ }^{76}$ The advantage of such a regime for the enterprise is obvious. It will have certainty with respect to the amount to be paid, which is never the case when it is subjected to full unlimited liability. In addition, the amount reserved for compensating environmental damage (through either insurance, a payment in cash, a bank guarantee or any other financial guarantee to be approved by the agency) can be paid back after the operations if no environmental damage occurred. Hence, the money is not lost as is the case with insurance premiums paid. From society's point of view the advantage is that there is at least the certainty that an amount of money deemed adequate to compensate damage will be available if an accident happens. ${ }^{77}$

\subsubsection{Advancement fund}

A second arrangement referred to as a "fund" is the advancement fund. The prepayment or advancement construction is a remedy for long-lasting civil procedures concerning liability and insurance coverage issues that can last much longer than the life of the victim. Especially in the case of asbestos victims it has been argued that it is highly unfair that (relatives of) victims only receive compensation post mortem because of the relatively short time between the discovery of the illness and their death. Therefore an advancement fund has been established in countries such as the Netherlands as remedy for asbestos victims. $^{78}$

Examples of these advancement funds can, for instance, be found in environmental legislation. In Belgium the Act of 10 January 1977 set up an advancement fund for damage caused by groundwater extraction. ${ }^{79}$ Again it is uncertain whether this advancement fund can play a large role in cases of catastrophic risk. The reason why compensation funds are sometimes defended with respect to these risks is not so much related to long-lasting procedures, but refer more to the uninsurability of certain risks or to the fact that no individual injurer can be identified. If these are the problems to be solved, an advancement fund is no adequate remedy.

\subsubsection{Guarantee fund}

Guarantee funds are well-known as instruments to protect victims against the possible insolvency of a liable injurer or his insurer. The advantage of a guarantee fund is that it only intervenes for the so-called excess risk, that is, the risk for which in the specific case for various reasons no insurance coverage is available.

However, it is essential that a guarantee fund only intervenes if other compensation mechanisms such as insurance have failed. The possible role of a guarantee fund for compensating damage will be discussed below.

76 See H. Bocken, M. Faure, W. Lambrechts, M. Boes, A. Nauw and L. Lavrysen (Note 70 above) pp. 31-32. It is based on earlier work of, inter alia, H. Smets, "Pour une indemnisation garantie des victimes de pollution accidentelle", in H. Bocken and D. Ryckbost (eds.), Insurance of Environmental Damage, 1991, pp. 397-423.

77 This is hence not a real "fund" but rather the guarantee we explained above.

78 More particularly by the Dutch Socialist Party (Socialistische Partij), see P. Swuste, "Van Individuele 'Asbestprocessen' naar een Asbestfonds?", Arbeidsomstandigheden, 1996, pp. 119-122; for a critical analysis see M. Faure and T. Hartlief, "Een Asbestfonds als Alternatief voor de Aansprakelijkheid van de Werkgever?", Tijdschrift voor Sociaal Recht, 1996, pp. 37-43.

${ }_{79}$ See for a detailed discussion H. Bocken, "Van fout naar risico. Een overzicht van de objectieve aansprakelijkheidsregelingen naar Belgisch recht”, Tijdschrift voor Privaatrecht, 1984, pp.368ff. 


\subsubsection{A general compensation fund}

A fourth alternative could be the compensation fund that would generally operate as a substitute for liability and insurance. Although it is often not specified, one has the impression that it is usually in that sense that the term "compensation fund" is used. ${ }^{80}$ However, if these compensation funds were to be used as an alternative to the liability system, inevitably the question arises how they can be financed in an adequate way. Therefore we shall now focus on basic differences between compensation funds, on the one hand, and liability combined with insurance, on the other hand, as devices to provide compensation for damage.

\subsection{General principles of fair and efficient compensation}

No matter how a compensation system is organized, the incentives for prevention of damage should always remain intact. This is important as well when it comes to judging the effectiveness of alternative compensation mechanisms. Liability rules do not just have a compensating, but also a preventive effect. Liability rules can only have a preventive effect if the duty to compensate is laid on the person who actually contributed to the risk. This means that a duty to compensate should in principle only rest with the person who actually contributed to the risk.

A second, related principle is that this duty to contribute should also relate to the degree to which the specific activity or operator contributed to the risk. This principle is usually automatically respected in liability law. The duty to compensate under tort law is indeed usually limited to the damage that the specific tortfeasor caused himself. ${ }^{81}$ However, also if compensation is paid collectively, it remains important to guarantee that the tortfeasor only contributes financially in relation to the degree to which he contributed to the risk as well. This is reflected in insurance policies in the well-known idea of risk differentiation. It simply means that bad risks pay a higher premium than good risks. This principle should also be applied if a compensation fund is set up, meaning that bad risks should contribute more to the compensation system than good risks. This is important since it will give incentives for prevention to the contributors to the fund. Bad risks will be punished and good risks should be rewarded.

These principles are not only important from an efficiency point of view (providing optimal incentives for prevention), but also include a fairness element. Indeed, if these principles were not followed, it would mean that good risks would have to pay for the bad risks as well and would therefore in fact subsidize bad risks. This negative redistribution should be avoided and therefore the compensation mechanism, fund or insurance, should be financed principally by the ones who really contribute to the damage.

In sum, the compensation mechanism should aim at differentiating between the contributions due. This differentiation is only possible if the insurance company or agency

80 For an overview concerning the current use of various compensation funds, see H. Bocken, "Systèmes Alternatives pour l'Indemnisation des Dommages dûs à la pollution", Revue Génerale des Assurances et des Responsabilités, 1990, pp. 11698-11714 and H. Bocken (Note 79 above) and see H. Bocken, "Complementary Compensation Mechanisms. A General Environmental Damage Fund?”, in H. Bocken and D. Ryckbost (eds.), Insurance of Environmental Damage, 1991, pp. 425-437.

81 Unless there was joint and several or channelling of liability. See on this, M. Faure, "Causal uncertainty, joint and several liability and insurance", in H. Koziol and J. Spier (eds.), Liber Amicorum Pierre Widmer, Vienna, Springer, 2003, pp. 79-98. 
administering the fund also possesses information on the degree to which the specific activity contributed to the risk. One key element in determining the choice between insurance or funds is therefore who possesses the best information to control the risk.

\subsection{Funds versus insurance}

\subsubsection{Risk differentiation}

Applying the principles discussed above, there are not many reasons why, if both are, in theory, available, a compensation fund would provide better protection against insolvency than the private insurance markets. One might assume that an insurer is better able to differentiate risks, since an insurer is specialized in risk differentiation and risk-spreading. Insurers possess techniques to determine in what way their insureds contribute to the risk. This assumes that the insurance markets are competitive. In the absence of competition on insurance markets, either the supply of insurance coverage could be too limited or premiums could be excessively high, which could justify a preference for a compensation fund. ${ }^{82}$ But if insurance markets are competitive, insurers can be assumed to be better able to deal with classic insurance problems such as moral hazard and adverse selection than the administrators of a compensation fund. One cannot see why, as a matter of principle, a government agency that runs a compensation fund would have better information on risks than an insurer. This might, however, be different if highly technical risks are involved where operators of certain facilities are in a much better position than the insurance company to monitor each other. Some examples have been given above. ${ }^{83}$ This point has been made for instance concerning compensation for nuclear damage. One could argue that a risk-sharing agreement between nuclear plant operators could lead to an optimal monitoring between the operators since they possess much better information on prevention, good and bad risks than an insurance company would. ${ }^{84}$ Also in maritime insurance, the Protection and Indemnity Clubs, which we already discussed, which are based on a mutual risk-sharing between shipowners, play a crucial role. ${ }^{85}$ With respect to these highly specialized matters one could therefore argue that the operators themselves might in some cases be better suited than an insurance company to control moral hazard since they are better able to process information on the particular risk. However, the examples given show that with these risk-sharing agreements no use is made of a government-run compensation fund.

\subsubsection{Costs}

Comparing insurance with compensation funds one should also address the comparative cost of both instruments. Insurance will generally be cheaper because liability insurance policies are not concluded for one activity but for a whole set of risks. There is

${ }^{82}$ M. Faure and R. Van den Bergh, "Restrictions of competition on insurance markets and the applicability of EC antitrust law", Kyklos, 1995, pp. 65-85.

83 See section 5 .

84 See M. Faure and G. Skogh, "Compensation for damages caused by nuclear accidents: a convention as insurance", GPRI, 1992, pp. 499-513 and M. Faure, "Economic models of compensation for damage caused by nuclear accidents: some lessons for the revision of the Paris and Vienna conventions", European Journal of Law and Economics, 1995, pp. 21-43.

85 See T.G. Coghlin (Note 55 above) pp. 403-416. 
hence one insurance policy with transaction costs that are incurred only once and an administrative structure within an insurance company that will be forced to reduce costs through competitive pressures. The costs of risk-spreading might also be lower with an insurance company than with a compensation fund. Insurers are indeed specialized in methods for acquiring information on differentiation of risks. In addition, it has been argued in the literature that insurance provides for a reduction of transaction costs between contracting parties, because parties can ex ante agree on a distribution of risks and losses in case of an incident. ${ }^{86}$ The comparison will also depend upon the type of compensation fund under discussion. In most cases one immediately thinks of a compensation fund run by a regulatory authority. If that is the case one can of course refer to the literature on the negative effects of bureaucracies to argue that such a publicly operated compensation fund should not necessarily provide compensation at lower costs than the private insurance market. This can be reduced if the fund is administered privately, but in that case competition with other funds has to be organized to provide incentives for cost reduction.

One could only think of cost advantages of a fund if one did not refer to it as one that would replace the liability and insurance system, but which would be a limitation fund, such as that proposed by the Interuniversity Commission, whereby potential injurers make an ex ante reservation for potential future losses.

In sum, if both insurance and compensation funds are available there is no clear reason why a fund would be the preferred solution. There may, however, be reasons why insurance might not be available to cover certain risks. ${ }^{87}$ In that case funds cannot be compared with insurance since insurance is no alternative.

\subsection{A general compensation fund for catastrophic risks?}

So far I have suggested that in general there are very few reasons to expect that a compensation fund would provide better compensation than a private insurance market. This is especially the case if one considers situations where the injurer can be identified and can be held liable. Fund solutions may however play a role in the situation where the injurer cannot be identified or is insolvent. ${ }^{88}$ In that case insurance is simply not available as an alternative. Let us look at the various functions that such a general fund could fulfil.

\subsubsection{Guarantee fund}

A compensation fund may well be used to guarantee compensation in case of insolvency of the injurer or his insurer. In that case a fund does not replace the liability and insurance system, but only intervenes in a particular case when the injurer or his insurer was

\footnotetext{
${ }^{86}$ This argument has been made by G. Skogh, "The Transactions Cost Theory of Insurance: Contracting Impediments and Costs”, Journal of Risk and Insurance, 1989, pp. 726-732.

$87 \mathrm{See}$, with respect to insurance problems concerning environmental risk in Belgium, H. Bocken, "L'Assurance Responsabilité Civile pour Dommages causés par la Pollution”, in Les Assurances de l'Entreprise, Actes du Collogues tenu à l'Université Libres des Bruxelles les 2 et 3 décembre 1993, pp. 239-280 and H. Bocken, "La réparation des Dommages causés par la Pollution au Droit Belge. La Situation en 1992", Tijdschrift voor Belgisch Burgerlijk Recht, 1992, pp. 284-327. See also H. Bocken and D. Ryckbost, Verzekering van Milieuschade, Insurance of Environmental Damage, 1991.

88 See e.g. H. Smets, "COSCA: A complementary system for compensation of accidental pollution damage", in P. Wetterstein (ed.), Harm to the environment: The right to compensation and the assessment of damage, 1997, pp. 223-248.
} 
found insolvent. This combined use of the liability system, insurance and a guarantee fund for the insolvency risk has the advantage that the incentives of the liability system will remain untouched and that the fund will only have to intervene in the event of insolvency. ${ }^{89}$

However, the question arises whether such a fund could be used at all separately from compulsory insurance (in the broadest sense). Indeed, if insolvency of the injurer is the problem one fears, it seems more logical to discuss the introduction of a duty to insure instead of immediately advancing a fund as a solution. If one looks at the use of guarantee funds now, one can note that they are usually used in case an insurance company goes bankrupt. This merits the question whether it is at all useful to provide for a duty to insure for particular risks. If we take the example of environmental damage, we should notice that so far only a few countries have introduced compulsory environmental liability insurance. ${ }^{90}$ However, it is important to stress that if one wishes to provide protection against the insolvency of the injurer it is more appropriate to focus on a variety of financial mechanisms, as discussed in this paper, that force a potential injurer ex ante to provide for compensation for future losses instead of focusing on an ex post fund solution. Generally, one may doubt whether it is useful to focus on a guarantee fund that should e.g. intervene in case of insolvency of an insurer instead of focusing on other ex ante compensation mechanisms to provide coverage.

\subsubsection{Restoration fund}

There is one other situation where insurance cannot intervene and a compensation fund could prove useful. This is where no individual enterprise can be identified as liable for the harm caused. ${ }^{91}$ Since there is no individual injurer who is liable there is logically also no insurer who will be bound to compensate. An example is the deterioration of a specific habitat through acid rain. These are typically cases where liability is not a suitable instrument. One might consider a compensation fund for these specific cases where no individual injurer can be found. However, the compensation fund should then be limited to those situations, so that liability rules and insurance can still exercise their preventive effects in all other cases where an injurer can be found.

Still the question will have to be answered, who should contribute to such a fund? Ideally this would be funded by all contributors to the risk. However, unlike the case of e.g. traffic accidents, it is not easy to identify ex ante what kind of activities contributed to the loss. If it is generally possible to argue that, say, sulphur dioxide emissions caused the loss economists would obviously advocate a pigovian tax on sulphur dioxide emissions to finance the fund. One reason, however, why environmental taxes are still relatively scarce in practice is that it will often be hard to determine to what proportion this specific activity contributed to the risk and hence to determine the optimal marginal tax rate. If this is not

89 This combined approach is also proposed by A. Monti, "Environmental Risk: A comparative law and economics approach to liability and insurance", ERPL, 2001, pp. 19-58.

90 For instance Germany, see G. Wagner, "Umwelthaftung und Versicherung”, Versicherungsrecht, 1991, pp. 249-260; G. Wagner, "Die Zukunft der Umwelthaftpflichtversicherung", VR, 1992, pp. 261-272 and G. Wagner, "Versicherungsfragen der Umwelthaftung", in M. Ahrens and J. Simon (eds.), Umwelthaftung, Risikosteuerung und Versicherung, Berlin, Erich Schmidt Verlag, 1996, pp. 97-146.

91 Other causes of failure of traditional liability and insurance are discussed by H. Bocken, "Deficiencies of the system of liability and liability insurance as a mechanism for the indemnification of environmental damage suffered by individual victims", in H. Bocken and D. Ryckbost (eds.), Insurance of Environmental Damage, pp. 133-145. 
possible, the only alternative is that the government will pay for the restoration of the specific site, either directly or by financing a compensation fund that has to finance the clean-up activity. However, since in each case it is the taxpayer who will have to provide the financial means, one might question whether setting up a compensation fund has any added value, apart from the fact that one can be certain that specific public funds will be reserved for compensation in case of that particular damage.

\subsection{Summary}

Many phenomena that include a private or public compensation scheme for particular damage are referred to as "fund" solutions. We have taken a brief look at some of these solutions, comparing them to traditional liability and insurance. Most discussed is a compensation fund that would totally replace traditional insurance. When an injurer can be identified, can be held liable and is solvent, a compensation fund can probably not play the important role it is expected to do. Generally insurance seems better able to control risks and can be provided at lower costs.

It seems therefore more appropriate to use traditional liability and insurance as far as possible and to use funds only in cases where insurance markets fail and there is reason to believe that funds would be able to provide adequate compensation. In that respect a guarantee fund comes to mind to provide coverage if an insurance company goes out of business. However, it does not seem useful to introduce a guarantee fund without a corresponding duty to insure.

It might be more interesting to focus on various other legal instruments that aim to provide protection against the insolvency of the injurer, discussed previously in this paper. The Convention of Lugano on civil liability for damage resulting from activities dangerous to the environment also provides for such flexibility by prescribing in Article 12 that operators are required to participate in a financial security scheme or to maintain a financial guarantee up to a certain limit. This should not necessarily be insurance. More flexible than a duty to insure is also the oft-mentioned proposal of the Flemish Commission to force a potential injurer ex ante to provide any kind of compensation, bank guarantee, or some other kind of payment ex ante as guarantee of compensation in the event of damage occurring. The advantage of this solution is that it does not replace liability. It provides for a flexible system whereby the potential polluter can choose any market solution, provided that it will be able to adequately compensate damage ex post.

Still this may not solve the situation whereby the damage had a variety of causes and no individual injurer can be identified. For these kinds of situations a fund might be warranted, although it is still unclear how this should be financed. If the injurers can be adequately identified as well as the degree to which they contributed to the risk, the fund could be financed through a tax on the risky activities. Otherwise the general tax system should intervene, but then the necessity for a fund disappears.

Generally, it seems important to analyse carefully the joint use of liability rules, insurance and funds. ${ }^{92}$ This may lead to a combined use of these systems whereby the incentives provided through liability rules can remain unaffected. A fund might provide a useful contribution for the specific case in which the damage cannot be tracked down to particular injurers.

92 So correctly A. Monti (Note 89 above). 


\section{Concluding remarks}

In this paper, I have analysed whether other financial arrangements could be advanced, other than traditional liability insurance, especially to cope with larger risks. The central question was whether there are mechanisms that can remedy the uninsurability of liability. This question of alternative financial arrangements and new financing techniques is an essential one in light of the fact that liability rules will have a deterrent effect only if the insolvency risk can be cured through the availability of financial securities. Otherwise the insolvency problem may lead to underdeterrence. The development of the liability insurance market in some countries, with respect to particular liability risks, may well be relatively weak. This was, for instance, the case with environmental risks, but may be the case as well with other newly emerging risks, such as risks related to new technologies. The problem in those cases is that the necessary information to make an adequate risk assessment may be lacking, as a result of which traditional insurance markets may not immediately wish to engage in the coverage of these risks. Moreover, problems of scale and capacity with large risks may be so big that traditional insurance markets may not be able to deal with them adequately. This justifies the question of whether alternatives are available, both within and outside traditional insurance markets. We have looked at various alternatives, both in theory and in practice. Indeed, one can see that in various areas new financing techniques to deal with risk have been developed.

One of the best known alternatives outside traditional insurance is the use of capital markets. This idea, which has been advanced mainly by economists, is theoretically sound. Investors could purchase "risk bonds" and stock prices would reflect the perception of the investors as to the riskiness of the activity. In theory this instrument might well work, although it will be clear that only larger investors who are also able to recognize good and bad risks, will be engaged in such a market. Until now the use of capital markets to deal with risks has mainly been limited to the U.S., although some advocate this new instrument in Europe as well.

Self-insurance may be a valuable alternative as well. Especially larger enterprises, who may be exposed (as injurer or victim) to larger risks may be able to cover a large part of the losses themselves, and so not need to purchase additional financial security. Indeed, one should not forget that the purchase of additional financial securities will always lead to an additional cost. Thus one may well understand why enterprises exposed to risk may primarily self-insure. However, although the instrument of self-insurance is certainly useful, there are also some doubts surrounding it. If, at the policy level, one wants to make sure that sufficient coverage will be available in case an accident occurs, it may be clear that selfinsurance is not a very reliable alternative. The key issue is indeed that securities should be provided that victims will be compensated in case of an accident. Moreover, it should also be made clear that these funds are available for victims only and not for other creditors (or e.g. for the trustee in bankruptcy). Self-insurance may not be able to provide these guarantees. Moreover, in many cases self-insurance is not a type of insurance in the traditional sense, since it does not contain an element of risk-spreading. It can, however, be considered as an instrument of financial security or, as it is sometimes referred to, financial "assurance".

The same is true for another alternative that is often mentioned, the use of so-called captives. Often captives are presented as separate forms of financial security, whereas it is in fact rather difficult to characterize them precisely, given that their nature may differ considerably. In some cases, captives have taken on a legal personality and constitute a separate capital which is in fact a reserve made by a particular company for future risk. In 
that specific case, a captive does not constitute a form of insurance, but the creation of the captive has tax advantages. Otherwise a reserve for future risk may not always be taxdeductible, depending upon the tax rules applicable in the particular legal system. In some cases, captives are set up by various companies and imply some form of risk-spreading. However, captives, although they can be highly useful for the enterprises involved, may pose the same problems as self-insurance, at least from a public policy perspective. Indeed, unless specific legal rules apply, there is not necessarily a guarantee that the capital available via the captive will also be available for accident victims ex post.

Therefore other alternatives have been examined as well. One can see an interesting alternative within the insurance world itself, which is the tendency towards first-party or direct insurance. Theoretically one can indeed argue that the key remedy for uninsurability, adequate risk differentiation, may be better applicable in case of first-party or direct insurance than in case of liability insurance. Hence, one can understand the tendency in many countries to move towards first-party/direct insurance solutions for particular risks. One can see this, for instance, in the area of occupational health, where employers will take out direct insurance on behalf of their employees guaranteeing compensation e.g. in case of an accident at work irrespective of the employer's liability. A similar trend can be seen in environmental insurance. We presented the Dutch experience with environmental damage insurance, showing that this new instrument may allow more effective compensation than traditional liability insurance. The scope of coverage (and therefore the compensation involved) will depend upon the contents of the insurance policy, but early experience with this new instrument seems quite promising. It is clear that this new insurance technique has now been introduced directly as a reaction to growing problems of insurability of liability risks.

We have also shown that in some cases and for some particular risks, risk-sharing agreements by operators have been promoted. These may achieve good results if either capacity on insurance markets is limited or it can be assumed that the information needed to optimally control risk (and therefore moral hazard) is better available from the operators themselves than from insurers. Experiences with some larger risks (oil pollution and the nuclear risk) have shown that these risk-sharing agreements may in some cases provide better results than traditional liability insurance. An advantage of these alternative arrangements is, moreover, that one does not necessarily need adequate information on the predictability of the risk ex ante, provided that adequate monitoring is possible.

Within the scope of this paper, I could only discuss a few new insurance and financing techniques. However, there are a variety of other arrangements provided by financial markets, such as ex ante guarantees or deposits into an environmental savings account. We have discussed only briefly proposals by the Flemish Interuniversity Commission allowing for a variety of financial instruments which could be used by the operator to meet his duty to provide financial security.

On balance, it is important that, at the policy level, it does not seem useful or appropriate to make a decision in favour of one particular financial or insurance instrument. It seems better to take into account the existence and working of all these financial and insurance institutions. If the policymaker wanted to be sure that financial guarantees are available, that damage would be covered ex post, it would be better to give a particular agency or administrative authority the task of assessing whether the financial security offered is effective. This means that the agency would have to check that it can be guaranteed that the money will ultimately be available when it needs to be used, meaning when the risk materializes. That point obviously remains a crucial one and is a major 
weakness with so-called self-insurance or captive schemes. However, the necessary flexibility remains important. Thus, depending upon the structure of the particular financial or insurance markets enterprises may wind up with a variety of instruments to cover future losses. Experience shows that this flexibility will have the advantage of pushing industry towards investments in research to discover optimal ways to cover risks. ${ }^{93}$ Take the example of the nuclear risk: the problems on the traditional nuclear liability insurance market have led operators (and in some cases insurers) to develop new instruments such as the risksharing agreements mentioned above. Thus the policymaker should always take into account that the legislation should be structured in such a way that it provides adequate incentives to operators to develop new financial and insurance techniques which may lead to additional coverage.

There remains, however, one important weakness with all of these alternative financial arrangements. They all suppose that a known source can be found to which the particular loss can be attributed. It is then assumed that this known source (a polluter, tort feaser or injurer) can be made liable and be held to pay compensation. In many cases, however, it may not be possible to attribute the damage risks to a particular source. The reasons may be manifold. There can either be problems in proving the causal link between the damage and a particular source, or there may be problems due to the legal system, e.g. in proving wrongfulness in tort. For that reason, many accidents may remain uncompensated. This again demonstrates the case for first-party insurance by victims, discussed above. On the other hand, one may also wonder whether this points to a need for government intervention. Indeed, first-party insurance may also not be able to cope with all problems. In some cases, the reasons for uninsurability in liability insurance will remain if one turns to first-party insurance. Consider terrorist attacks: the problems caused may be so huge that the capacity problems inherent in insurance would also remain if one moved to first-party solutions. Many problems facing the insurance and reinsurance world today as a result of the attack on the Twin Towers on 11 September 2001 are in the sphere of first-party insurance. If the limits of first-party insurance coverage are reached, the public will inevitably call on the government to intervene. Hence, for those cases where traditional insurance markets fail to provide coverage, government intervention, e.g. by creating a compensation fund, may be warranted

93 This has been particularly experienced in the U.S., according to J. Boyd, "A market-based analysis of financial insurance issues associated with U.S. natural resource damage liability", in M. Faure (ed.), Deterrence, insurability, and compensation in environmental liability. Future developments in the European Union, Vienna, Springer, 2003, pp. 258-302. 